University of Michigan Law School

University of Michigan Law School Scholarship Repository

\title{
The Product/Process Distinction - An Illusory Basis for Disciplining 'Unilateralism' in Trade Policy
}

\author{
Robert L. Howse \\ University of Michigan Law School \\ Donald H. Regan \\ University of Michigan Law School, donregan@umich.edu
}

Available at: https://repository.law.umich.edu/articles/1514

Follow this and additional works at: https://repository.law.umich.edu/articles

Part of the International Trade Law Commons, Organizations Law Commons, and the Transnational Law Commons

\section{Recommended Citation}

Howse, Robert L. "The Product/Process Distinction - An Illusory Basis for Disciplining 'Unilateralism' in Trade Policy." Donald H. Regan, co-author. European Journal of International Law. 11, no. 2 (2000): 249-89.

This Article is brought to you for free and open access by the Faculty Scholarship at University of Michigan Law School Scholarship Repository. It has been accepted for inclusion in Articles by an authorized administrator of University of Michigan Law School Scholarship Repository. For more information, please contact mlaw.repository@umich.edu. 


\title{
The Product/Process Distinction An Illusory Basis for Disciplining 'Unilateralism' in Trade Policy
}

\author{
Robert Howse and Donald Regan*
}

\begin{abstract}
It has become conventional wisdom that internal regulations that distinguish between products on the basis of their production method are GATT-illegal, where applied to restrict imports (although possibly some such measures might be justified as 'exceptions' under Article XX). The aim of this article is to challenge this conventional wisdom, both from a jurisprudential and a policy perspective. First, we argue there is no real support in the text and jurisprudence of the GATT for the product/process distinction. The notion developed in the unadopted Tuna/Dolphin cases that processed-based measures are somehow excluded from the coverage of Article III (National Treatment) and are therefore violations of Article $X I$ (quantitative restrictions) is inconsistent with the text of this provision and the basic structure of the GATT. The real question is whether, under the National Treatment standard of Article III, products may be considered 'unlike' due to process-based differences. We argue that regulatory distinctions objectively related to actual non-protectionist policies are consistent with Article III, whether product-or process-based. The second half of the article addresses a range of policy concerns about treating process-based measures similarly to product-based measures under Article III. One concern is based on the conflation of process-based measures with measures that distinguish products not according to how they are actually produced, but rather according to their country of origin. We believe that country-based measures are likely to be violations of Article III and/or Article I of the GATT,

* University of Michigan Law School, rhowse@umich,edu donregan(dumich.edu We would like to thank Carolyn Frantz for excellent research assistance, and Arthur Appleton, Jagdish Bhagwati. Rick Hills, Petros Mavroidis, Kalypso Nicolaidis and Joel Trachtman for helpful and challenging conversations or emall correspondence with one or other of us on some of the issues addressed herein. Comments on an earlier draft from Steve Charnovitz, Paul Joffe, and Jocl Trachtman were also very helpful. We alone are of course responsible for the contents of the paper. We are also grateful for reactions when we presented this paper at the University of Michigan Law School/Luropean Journal of International Law Symposium on Unilateralism, Am Arbor, Michigan, and at the World Trade Organization, Economic and Legal Scminar series, Geneva, January 2000.
\end{abstract}

ETIL (2000), Vol. 11. No. 2, 249-289 
although under some circumstances they might well be justifiable under Article XX. We address other objections that relate to the purportedly 'unilateral', 'extraterritorial' or 'coercive' nature of process-based measures, and to the notion that they are likely to be protectionist or to result in greater market segmentation, or impose unfair or distributively unjust costs on producers in developing countries, drawing on the economic theory of externalities to justify our conclusion that the rationales and effects of process-based measures do not systematically differ from those for product-based regulations.

\section{Introduction}

There is arguably nothing that has served to focus public attention and criticism of the multilateral trading system more than the system's response to governmental efforts to protect the global environment through trade action. Individuals who know little about the trading system nevertheless are likely to have heard of the infamous Tuna/Dolphin cases, ${ }^{1}$ where a GATT dispute settlement panel largely shut the door to the possibility of GATT members taking unilateral trade action to protect the global environment, despite the lack of any treaty provision prohibiting such action, as well as the presence of explicit exceptions in Article XX of the GATT, which allow otherwise GATT-inconsistent measures where 'necessary to protect human, animal or plant life or health' (Article XX(b)) or where 'relating to the conservation of exhaustible natural resources if such measures are made effective in conjunction with restrictions on domestic consumption and production' (Article XX $(\mathrm{g})$ ).

Although neither of the Tuna/Dolphin panel rulings was adopted by the membership as a legally binding solution to the dispute, they came to represent to many people the basic hostility of the trading system to values other than that of trade liberalization itself. Finally, last year, in a case involving trade measures analogous to those at issue in Tuna/Dolphin (a ban on imports of shrimp from countries that did not require shrimping technology that avoided the incidental killing of sea turtles) the Appellate Body of the World Trade Organization set forth a fundamentally different reading of Article XX of the GATT. The Appellate Body held that: "[it] is not necessary to assume that requiring from exporting countries compliance with, or adopting certain policies (although covered in principle by one or other of the exceptions) prescribed by the importing country, renders a measure a priori incapable of justification under Article XX. Such an interpretation renders most, if not all, of the specific exceptions of Article $X X$, inutile, a result abhorrent to the principles we are bound to apply. ${ }^{2}$ At the same time, the Appellate Body found that there were some elements in the application of the US measures in practice that ran afoul of the chapeau or preambular paragraph of Article XX in constituting 'arbitrary or unjustifiable discrimination between countries where the same conditions prevail'.

1 United States -..- Restrictions on Imports of Tuna, 30 ILM (1991) 1594; United States - Restrictions on Imports of Tuna, 33 ILM (1994) 936.

2 United States - Import Prohibition of Certain Shrimp and Shrimp Products, Report of the Appellate Body, 12 October 1998, WT/DS58/AB/R [hereinafter, Turtles AB ruling], para, 121. 
In the Turtles case, however, another prong of the Tuna/Dolphin ruling equally unsupported by the text of the GATT went unchallenged, because of a strategic decision by the appellant the United States not to put it in question on the facts of the Turtles case. Article III of the GATT disciplines discriminatory domestic regulatory measures. In Tuna/Dolphin, the panels held that even non-discriminatory measures, which conditioned the sale of both domestic and foreign tuna on the adoption of a particular, environmentally friendly technology, constituted violations of the GATT; they held, again without any plausible foundation in the text of the treaty, that regulatory measures based on the process or production method, rather than inherent or physical characteristics of the product itself, fell outside of Article III, and thus that such process-based measures, where applied to imports, constituted a violation of Article XI of the GATT, which prohibits restrictions and prohibitions on imports. The implication of this holding is that a huge number of non-discriminatory regulatory measures would have to be considered prima facie violations of Article XI of the GATT, and require justification under Article XX, merely because the policy concerns are raised by the process, rather than the content of the product. Underlying this holding is the notion that, when a country specifies the production processes for products it is importing, it is engaging in inappropriately or illegitimately 'unilateral' behaviour, determining something on its own that ought to be decided through international cooperation and negotiation, for example, the appropriate level of global environmental externalities that another country may create by engaging in a specific economic activity, Yet, of course, in the absence of negotiated rules or norms, leaving the country of production to make these determinations on its own, unconstrained by stipulations imposed by its trading partners who are importing the product, would itself be countenancing 'unilateralism', in this case, the unilateral determination by the country of production of matters that affect the global commons. Thus, in choosing a rule that constrained the 'unilateralism' of importing states, the panel was not favouring a multilateral solution over a unilateral one, rather it was simply preferring the 'unilateralism' of the producing state to that of the importing state. ${ }^{3}$

Nevertheless, it has become conventional wisdom that this distinction is now part of the 'law' of the WTO, and that it represents a main pillar of the trading system's response to unilateralism in trade policy. Thus, it is widely thought that all process-based measures not directly related to physical characteristics of the product itself are prima facie violations of GATT and therefore illegal unless they are justified under Article XX. Most discussions of the trade and environment issue now start from the premise that the process/product distinction is an established and uncontroversial

3 Precisely because the selective use of the expression 'unilateralism' to describe the conduct of the importing country in specifying process standards obscures the normative issues at stake in the debate around the process/product distinction, we have largely avoided the language of 'unilateralism' in what follows. Given that the theme of the Symposium was unilateralism, this might at first glance seem perverse - we have done so, however, not to avoid treating the phenomena conventionally characterized under the tag 'unilateralism', but rather to clarify those very phenomena and allow a more precise, and less polemically-loaded, articulation of the phenomena. Our strategy could be summarized in Husserl's dictum, 'to the things themselves!' ( $\mathrm{Zu}$ den Sachen selbst!). 
element of GATT doctrine, whether the authors like its environmental consequences or not. Yet, while it was not challenged in Turtles, it is likely that the processes/product distinction will not long remain untouched by WTO jurisprudence. One need only consider the case of genetically modified foods - the United States takes the position that genetic engineering is a process that does not affect the product as such. ${ }^{4}$

Our object in this paper is to defend process-based measures: first, to argue, against the Tuna/Dolphin panels, that process-based measures are within the scope of Article III, and are not remitted to Article XI; and second, to argue, against a popular and superficially plausible construction of the 'like product' language in Article III, that process-based measures are not in all cases prima facie violations under Article III. In fact, Article III does not distinguish in any way between process-based measures as a class and product-based measures as a class. In Part 2 below we shall examine the text and jurisprudence of GATT, to show that neither supports the process/product distinction. In Part 3 we shall consider conceptual and policy arguments. Despite the lack of support for the process/product distinction in the law of GATT, there is a widespread intuitive belief that the distinction is significant. This belief we will attempt to trace to its roots and extirpate in Part 3, where we discuss, inter alia, extra-territoriality, protectionism, market segmentation, and labelling requirements.

One clarification is in order immediately. In defending process-based measures, we are not defending every measure that makes some reference to processing method. In particular, we are not defending what we shall call 'country-based' measures, such as a prohibition on the importation of tuna from any country that allows dolphinunfriendly tuna fishing. Under such a 'country-based' measure, the importability of any particular shipment of tuna depends not on how that tuna itself was caught, but rather on what country it is from. This is discrimination along national lines; it is prima facie illegal under Article III; and if it is to be legal it requires justification under Article XX. ${ }^{5}$ (The claim that country-based measures are prima facie illegal is not likely to be controversial, but we shall say a little more in $3 \mathrm{~A}$ about the economic significance of the distinction between process-based and country-based measures.) So, what we refer to as 'process-based' measures are what would standardly be referred to as origin-neutral process-based measures.

We should note further that even within the class of (origin-neutral) process-based measures, some measures will be illegal because they involve disguised protectionism. But that is true of product-based measures as well. As we say, there is no distinction of principle to be made here. For reasons we shall discuss in 3D, it may be that a higher proportion of the process-based measures that are suggested in political debate would

4 'The method by which food is produced or developed may in some cases help to understand the safety or nutritional characteristics of the finished food. However, the key factors in reviewing safety concerns should be the characteristics of the food product, rather than the fact that new methods are used.' Food and Drug Administration, Statement of Policy: Foods Derived from New Plant Varictics, Fed. Reg. $22,984,22,985(1992)$.

5 Even more obviously problematic are measures that forbid the import of all products from a country that allows dolphin-unfriendly fishing, and intermediary-country measures. For the most part, our discussion will ignore these entirely. 
be protectionist if adopted (though most of the worst have remained merely topics for discussion). We shall explain, for example, why process-based measures extending internal labour legislation are often more suspect than measures extending environmental legislation. It may reassure the reader if we emphasize now that our rejection of the process/product distinction does not commit us to endorsing every possible 'level playing-field' argument.

\section{The Law on Origin-neutral Process Measures: Text and Jurisprudence}

In order to understand the significance of the product/process issue, it is first of all necessary to understand the place of Article III in the structure of GATT as a whole. Article III.(4) of the GATT is a cornerstone of the multilateral trading system, defining the approach of the system to domestic regulation which may have an effect on trade. The National Treatment obligation contained in Article III(4) establishes discrimination as the key concept in distinguishing legitimate and illegitimate domestic regulation. The choice of discrimination as the key concept is of central importance to the basic 'deal' represented by the GATT: although an almost infinite range of domestic policies may have some kind of impact on trading opportunities or market access, only those which are discriminatory, and therefore putatively protectionist, will be subject to prohibition. ${ }^{6}$ Border measures of the kind prohibited in Article XI (quantitative restrictions) or constrained by Article II (which prohibits tariffs and other charges in excess of bound rates) are, of course, also normally discriminatory against imports. These also may entail, in certain circumstances, discrimination for justified, non-protectionist purposes, such as health, safety, environmental and national security reasons. Thus, where a measure is found to violate Articles III, XI or II (and is not saved by any provision within the GATT itself, such as the safeguards/escape clause in Article XIX), nevertheless it might be capable of justification within one of the exceptions of Article XX, provided that the measure is not applied in such a manner as to create 'arbitrary' or 'unjustifiable' discrimination or a 'disguised restriction on international trade'. It is important to bear in mind, however, that not all public policy purposes widely viewed as legitimate or important in liberal democratic societies are covered by the exceptions in Article XX - for example, consumer protection (unless the issue is one of human health or safety or deceptive practices).

\section{A The Coverage of Article III}

The unadopted panel reports in Tuna/Dolphin $I$ and $I$ claimed that process measures were simply not covered by Article III (and were therefore remitted, in those cases, to

6 See Sykes, 'Regulatory Protectionism', 66 University of Chicago Law Review (1999) 1.

7 This is not to say that regulations that deal with fraud or deceptive practices might not be justifiable under Article XX(a) as 'necessary for the protection of public morals'. The meaning of public morals has never been addressed in a GATT/WTO dispute settlement. 
Article XI). It is perhaps worth remembering that the measures in those cases were country-based, but the panel's arguments, if valid, would apply to origin-neutral measures as well.

The Tuna/Dolphin I panel's argument is by no means clear, since the panel introduces without definition the notion of measures 'affecting products as such' and the notion of how a measure affects a product 'as a product'. Still, the main line seems to go as follows. The panel makes much of the fact that the various sections of Article III refer to laws and regulations that affect the sale, purchase, transportation, and so on, of 'products'. This, it says, 'suggests that Article III covers only measures affecting products as such' (para. 5.1.1). The panel then implies that process-based measures do not 'affect products as such' or 'affect the product as a product', suggesting the following three reasons: (I) 'products as such' are defined by their physical constitution, and process-based measures affect differently products that have exactly the same physical constitution; and/or (2) regulation of the production process just is not regulation of products; and/or (3) the process-based measures do not affect the ultimate physical constitution of the product. It follows that Article III(4) does not cover process-based measures. (The panel does not focus on the issue of 'like' products, which we will discuss below, presumably because that leads to an argument about the substance of Article III, not the coverage.)

Despite the panel, it should be obvious that the repeated reference to 'products' tells us nothing about the product/process distinction. It merely reflects the fact that GATT is about trade in goods, not about trade in services or the movement of capital or labour. We could show in detail that none of the panel's three sub-arguments actually applies the text (as opposed to improvising on one of its key terms), but a detailed treatment is unnecessary. The panel's larger argument falls under its own weight if we simply compare the conclusion to the text the argument purports to analyse. The text of Article III(4) says it applies to 'internal laws, regulations and requirements alfecting the internal sale ... of products'. Who could doubt that, giving terms their ordinary meaning, process-based measures 'aflect the sale of products'? This is true even of the ban on the use of dolphin-unsafe fishing techniques by United States fishermen (the panel's prime example of a regulation not affecting tuna 'as a product'), ${ }^{8}$ since the ban almost certainly affects the price and quantity of tuna sold. But more important, the whole complaint about the United States' regime is that it affects the sale of products by reducing the sales of foreign tuna.

It might be objected that our ordinary language reading of 'affecting the ... sale' is so broad that it makes the text's further references to 'offering for sale, purchase, transportation, distribution, or use' redundant. There is something in this, But the only way to avoid the redundancy would be to read 'affecting' so that it means 'having its immediate regulatory impact on the precise activity of ...' and this reading, in conjunction with the text's list of activities, would exclude from the coverage of the Article regulations about possession, storage, advertising, registration, post-purchase products liability, and so on. This is a case where one just has to admit that there is 
redundancy in the text of the Article. Overlap of similar terms in a series (which are often proliferated just to insure complete coverage) is not at all the same thing as a pointless sentence or an inutile section.

If we look at the jurisprudence, we will find confirmation both of the broad reading of 'affecting the ... sale' and more specifically of the applicability of Article III to process-based measures. In Italian Discrimination Against Imported Agricultural Machinery. ${ }^{9}$ the panel famously opted for a broad reading of 'affecting the ... sale' in applying Article III to the Italian government's programme of subsidized loans for purchasers of Italian, but not foreign, farm machinery, "The selection of the word "affecting" [implies] ... that the drafters of the Article intended to cover in paragraph 4 not only the laws and regulations which directly governed the conditions of sale or purchase but also any laws or regulations which might adversely modify the conditions of competition between the domestic and imported products on the internal market' (para. 12). Similar is Canada - Administration of the Foreign Investment Review Act, ${ }^{10}$ which applies Article III to domestic sourcing commitments undertaken by foreign investors as a condition of governmental approval for their investments. And a case which it would be impossible to shoehorn into any narrow reading of 'affecting the ... sale, etc,' is United States - Section 337 of the Tariff Act of 1930, applying Article III to procedural aspects of infringement proceedings under United States patent law. ${ }^{11}$ On the precise point of the application of Article III to process-based measures, the adopted panel report in United States - Measures Affecting Alcoholic and Malt Beverages ${ }^{12}$ applied Article III without hesitation to an origin-neutral micro-brewery tax credit; and the unadopted report in United States Taxes on Automobiles ${ }^{13}$ similarly applied it to the origin-neutral aspects of the fleet-accounting requirements. ${ }^{14}$ Finally, there are a number of adopted reports applying Article III to country-based process measures. From our point of view, these are a rather different kettle of fish from origin-neutral measures, but since the Tuna panels made no such distinction and actually applied their argument to country-based measures, it is worth mentioning the Section 337 case and even the venerable Belgian Family Allowances (which said

BISD 7 (1958).

10 BISD $30(1984) 140$.

1) BISD 36 (1989) 345. Incidentally, patent laws seem a glaring counter-cxample to the claim that process-based measures are per se illegal. Patent laws discriminate between physically identical goods on the ground of their processing history (in the most literal sense when what is in issue is whether a patented process has been lllegally used, but also when the patent is on the product and we focus on the character of the producer as licensed or unlicensed). Perhaps people are unimpressed by this example because they think $\Lambda$ rticle XX(d) specially exempts patent law. But if we consider the syntax, XX(d) presupposes that patent law is 'not inconsistent with the provisions of this Agreement'.

12 BISD 39 (1992) 206 (hereinafter, Beer II).

13 WT/DS31/R (11 October 1994, unadopted).

14 The Appellate Body has told us that unadopted reports have no authority whatsoever, Argentina Measures Affecting Imports of Footwear, Textiles, Apparel and Other Items, Report of the Appellate Body, adopted 22 April 1998 , WT/DS56/AB/R, but it still seems appropriate to mention the unadopted US Taxes on Automobiles panel, supra note 13, in responding to the persistently influential Tuna/Dolphin reports, especially since the Taxes panel makes essentially Tuna-style arguments, but to the end of showing a violation of Article III, not non-coverage. 
only that there was 'possibly' an Article III violation, but not in a context that suggested any doubts about the Article's applicability),

It may seem that the Appellate Body's recent decision in Turtles ${ }^{15}$ reaffirms that process-based measures are to be reviewed under Article XI, not Article III. The Appellate Body did not address the issue, because it was not contested on appeal. But that left the panel's finding of an Article XI violation in place. The panel relied partly on mischaracterizing the United States' refusal to dispute complainants' allegation of an Article XI violation as an admission that there was one. But beyond that they had a respectable procedural argument: a law that takes the form of an import ban is a prima facie violation of Article XI, and if a tribunal is to consider the argument that the import ban is instead an internal regulation by virtue of the Note $A d$ Article III, then it is up to the respondent, whose laws are in question, to bring forward evidence of the internal scheme that the import ban is said to enforce at the border. It cannot be up to the complainant to negate the existence of any relevant internal scheme. This justifies the finding of an Article XI violation when the respondent refuses to defend an import ban; but it obviously says nothing of substantive significance about the status of process-based measures. ${ }^{16}$

Leaving aside the precise words of the text and the cases, the claim that Article III does not cover process-based measures, if taken seriously, would have totally unacceptable consequences. It served the panel's purposes well enough in Tunal Dolphin $I$ and $I I$ only because the measures, if not covered by Article III, could be regarded as falling under Article XI. But consider Minnesota's origin-neutral tax credit for micro-breweries in Beer II. This is a process-based measure, so according to the Tuna/Dolphin panels, it is not covered by Article III. But it is not a quantitative restriction or a border measure, so it does not come under Article XI either. It escapes review entirely, as will any process-based measure that is enforced internally even against foreign products. This insulates internally enforced process-based measures from an inquiry into disguised protectionism and puts them in a better state than product-based measures, which no one intends. ${ }^{17}$

The Tuna/Dolphin panels fell into the trap of treating Article III as if its function were

15 Supra note 2.

16 The United States' decision not to contest the Article XI issuc may be explained by the fact that the regime as applied was country-based, and thus would have been a violation even if reviewed under Article III. (There are complications raised by the contemporaneous litigation in United States courts about the interpretation of the regulation that are not worth discussing in detail.) Also, by persuading the $A$ ppellate Body to find that their country-based process measure came within Article XX(g), the United States accomplished something of comparable importance to persuading them that an origin-ncutral process measure was not a violation at all.

17 We could avoid the absurd consequences, and get part of the result the panel wants, by saying that Article III can apply to process-based measures but the Note $\Lambda$ d Article III does not - so that any process-based measure which is enforced at the border will be reviewed under Article XI, while any process-based mensure which is enforced entirely internally can still be reviewed under Article III. But there is not the slightest grounding in the text for any such distinction between the coverage of Article III and of the Note. A diflerence of such consequence based on the form of the regulatory instrument is just what the Note Ad Article III was meant to avoid. 
to authorize measures which would otherwise be illegal - a way of thinking which is manifested in much discussion of Article III. If Article III were an 'authorizing' section, then any class of measures which was excluded from its coverage would be pro tanto worse off. But Article III is not an authorizing section, it is a prohibitory section, and therefore a class of measures which is excluded from its coverage is pro tanto better off. (The Note Ad Article III does have the permissive consequences of an authorizing section, since its function is to reallocate certain measures from the scope of Article XI to the scope of Article III, and Article XI more automatically condemns measures within its scope. But that does not change the nature of Article III itself.) The idea that Article III is an authorizing section goes along with the idea that GATT creates a general right of access for foreign goods, so that any measure which impedes their importation or distribution requires justification. Article III is then supposed to authorize internal measures which are even-handed. But GATT creates no such general right of access, even with an exemption for non-discriminatory measures; rather, it creates only a negative right that access shall not be restricted by discriminatory measures of various sorts. (The difference is important, inter alia, for thinking about burdens of justification and burdens of proof. $)^{18}$ Aside from the fact that nothing in the text purports to grant a general right of access (and any contrary appearance in Article XI is negated by the Note Ad Article III), the 'general right of access' view makes nonsense of the structure of the text. This view would mean that Article III was really an exceptions clause, which should be grouped with Article XX. And Article XI, which cannot be read as any sort of authorizing clause, would become inutile. (We cannot turn around and say Article XI is itself the statement of the general right of access, because then the right would be much too narrow. There would be no protection against discriminatory internal measures.) The split between the 'general right of access' view and the 'specific right against discrimination' view represents the deepest intuitive divide in approaches to GATT. We shall have more to say about the consequences of taking one side or the other in section 3C. But it seems clear which approach the text of the treaty dictates. ${ }^{19}$

is There is no substantive difference between the general right-of-access view and the right-againstdisctimination view as stated in the text, provided one does not exclude whole classes of non-protectionist regulations from the scope of Article III. But some people who incline to the gencral right-of-access view tend to forget about the idea of an Article III exemption for even-handed laws; as soon as it is shown that a measure impedes the importation or distribution of some foreign goods, they want to skip straight to Article XX. That creates a huge difference between the views, given the restricted range of policies that Article XX allows to ground an exception.

19 There are a few subsidiary arguments in the Tuna/Dolphin reports that deserve brief mention:

(1) The panel in Tuna I makes an argument based on the Report of the Working Party on 'Border Tax Adjustments', The panel quotes the following excerpt: '... there was convergence of views to the effect that taxes directly levied on products were eligible for tax adjustment [emphasis added by the panel] ... Furthermore, the Working Party concluded that there was convergence of views to the effect that certain taxes that were not directly levied on products were not eligible for adjustment [such as] social sccurity charges whether on employers or cmployees and payroll taxes.' The panel reasonably opined that the principle at work here should be applied (so far as it is relevant) to regulations as well as taxes; but they misunderstood the principle. The pancl assumed that the Working Party's distinction between 'taxes directly levied on products' and 'taxes that were not directly levied on products' was the same as the 


\section{B Operative Provisions of Article III}

\section{The Text}

We have established that Article III applies to process-based measures. What does it say about their legality, or more specifically, about the legality of origin-neutral process measures? Most people who think origin-neutral process measures are prohibited by Article III probably have in mind something like the following argument (which is also suggested by the Tuna/Dolphin panel reports): (1) 'Like products' means products which are alike in their physical properties. (2) Hence, products which differ only in their processing histories (where the difference of process does not cause any difference in the physical constitution of the product) are 'like'. Therefore, (3) foreign products, even if made with the disfavoured process, are entitled to the same treatment as domestic products made with the favoured process. ${ }^{20}$

Even granting for the moment that products which differ only in their processing

panel's distinction between regulations that did and did not regulate the product 'as such' or 'as a product'. Even if that were correct, the pancl would have overread the Working Party's conclusion, because the Working Party says only that 'certain' taxes of the second sort are ineligible for adjustment, not that all are ineligible. But in fact, the Working Party's distinction is not the panel's. Consider a special excise tax of 50 cents a can levied on the sale of canned dolphin-unsafe tuna. This is a process-based measure, which would be regarded by the panel as not levied on the product 'as such'; but in the Working Party's terms, this would be a 'tax directly levied on [the] product'. The Working Party's point, as their ensuing discussion makes clear, is that when the tax is directly levied on the product, in their ordinary-language sense, it is easy to tell what sort of adjustment is genuinely equalizing (indeed, in this measure the 'adjustment', which the Working Party notes need not happen at the border, is automatic); whereas when the tax is not directly levied on the product, it is difficult or impossible to ascertain what equalization requires.

(2) The panel suggests the further argument that the Note Ad Article III does not apply to the import ban in this case because the import ban, which regulates import of the product, is not 'of the same nature' as the domestic harvesting regulations. It is hard to take this argument seriously, since the whole point of the Note is to recognize that onc and the same legitimate policy may be even-handedly applied to local and foreign goods by different sorts of regulation. But in any event, the objection could be avoided by the United States adopting a sales ban on domestic dolphin-unsafe tuna, which pointless exercise the panel virtually suggests.

(3) The only thing the second Tuna/Dolphin ruling adds to these arguments is the statement that 'Article III calls for a comparison between the treatment accorded to domestic and imported like products, not for a comparison of the policies or practices of the country of origin with those of the country of importation' (para, 5.8) This is true, and irrelevant to our concern. A country-based measure would require the importing country to attend to the policics of foreign countries, but a country-based measure we already know is illegal (unless justified under Article XX). In contrast, in order to formulate and enforce an origin-neutral measure excluding dolphin-unsafe tuna, the importing country need not even cast a glance at the policy of any other country. The question is whether the importing country can act on its own non-protectionist policy of protecting dolphins. Plainly the general presumption of GATT is that countries can act on their own non-protectionist policies, and the panel's 'product/policy' distinction does not suggest any non-question-begging counter-argument. (Insofar as the panel is suggesting tortuously the straightforward argument that dolphin-safe and dolphin-unsafe tuna are like products and must therefore be treated alike, we shall deal with that in the next section.)

20 What the treaty says, of coursc, is treatment 'no less favourable'. It is convenient for discussion to treat this as a requirement of equal or same treatment. 
histories are 'like', the conclusion of this argument is a non sequitur. The treaty does not say foreign products shall be accorded the same treatment as the most favoured like domestic products. It says only that they shall be accorded the same treatment as like domestic products, simpliciter. Suppose Utopia wishes to discourage dolphinunsafe tuna fishing but not to prevent it entirely, so it passes a law saying that dolphin-unsafe tuna, whether domestic or imported, may be sold at retail only on Thursdays. Assuming for the moment that all tuna, however caught, is the same ('like') product, what treatment is accorded by this regime to domestic tuna? The obvious answer is that domestic tuna is accorded a conditional treatment, as follows: 'If dolphin-safe, sellable any day of the week; if dolphin-unsafe, sellable only on 'Thursdays.' But of course this treatment is accorded to foreign tuna as well, so there is no violation.

Thus, in the Tuna/Dolphin rulings, when the panels concluded that dolphin-friendly and unfriendly tuna were like products, they should not have rushed to the further conclusion that, since domestic dolphin-friendly tuna is treated differently from imported unfriendly tuna, protective discrimination exists. The text of Article III(4) does not provide for equal treatment of all 'like' products, but rather for equality as between domestic and imported 'like' products. So, if we assume with the panel that domestic and imported tuna are 'like' products, regardless of whether dolphinunfriendly or not, then we have to ask whether, by denying entry to dolphinunfriendly imported tuna, the United States was denying a competitive opportunity to imports that it affords to like domestic products. But like domestic tuna is not afforded greater competitive opportunities, since its access to the market also depends on being produced in a dolphin-friendly way; in sum the United States provides identical competitive opportunities to the 'like' domestic product, which according to the panel's own analysis is 'tuna'.

Let us return for a moment to our hypothetical case, where dolphin-unsafe tuna, whether domestic or imported, can be sold only on Thursdays. We have seen that if we understand the 'treatment' of domestic tuna as a conditional treatment, then foreign tuna is treated the same as domestic, and there is no prima facie violation under Article III. People who think there is a prima facie violation are implicitly thinking of the 'treatment' as unconditional, that is, as either 'sellable any day of the week' or 'sellable only on Thursdays', But if the 'treatment' is unconditional, then there is no treatment that answers to the text's specification of what foreign products are entitled to, namely 'that [treatment] accorded to like products of national origin'. There is no unique unconditional treatment that is 'accorded to like products of national origin', because domestic dolphin-safe tuna and domestic dolphin-unsafe tuna are both like products, but they are accorded different unconditional treatments. So, on the present interpretation of 'like product' and 'treatment', Article III(4) becomes impossible to apply. $^{21}$ (This problem is easy to overlook if we consider only cases where the importing country forbids the disfavoured process entirely, so that there is no

21 It might secm that we have produced a new argument for the Tuna/Dolphin I panel's position that Article IIJ does not cover process-based measures. But we have already seen that that is untenable. 
domestic product made with the disfavoured process to worry about. But surely it is clear that it should make no difference to our understanding of Article III whether the disfavoured process is absolutely forbidden to domestic producers or is merely saddled with regulations which subject products made with it to competitive disadvantage.) ${ }^{22}$

The root of the problem lies in the claim that physically identical products that differ only in their processing histories are 'like' products. The opponent of process measures thinks this follows from the ordinary meaning of 'like'. We disagree. 'Likeness' in this context is not primarily a matter of physical similarity. To see this, consider two pairs of products. One pair is vodka and shochu, which were held to be like products in Japan - Taxes on Alcoholic Beverages largely on the ground of their physical similarity. For the other pair, imagine two chemicals that are much more similar than vodka and shochu in their physical constitution (they might be very complicated molecules differing in only one atom), but such that one is harmless and the other is a dangerous explosive or a hideous neurotoxin. No one would think of suggesting that these two chemicals were 'like' products, despite their extreme similarity. Different regulation is obviously justified. Comparison of the vodka/shochu example with the chemicals example should make it clear that the issue of 'likeness' is distinct from the issue of physical similarity, and not even very closely related. The chemicals are much more physically similar than vodka and shochu, but they are much less 'like'.

If physical similarity is not the issue, what is? The real issue is the existence of differences between the products that justify different regulation. Regulatory distinctions must have a rational relation to some non-protectionist regulatory purpose; and therefore products must be treated the same (that is to say, they are 'like'), if and only if they do not differ in any respect relevant to an actual non-protectionist regulatory policy. This gives us the meaning of 'like' in Article III. 'Like' means roughly 'not differing in any respect relevant to an actual nonprotectionist policy'. This is not a recondite interpretation; it is the ordinary meaning of 'like' in this context. The context is a provision aimed at preventing a certain kind of discrimination. Any lawyer and any thoughtful non-lawyer (and these are the people for whom Article III was written) knows that in the context of a discussion of

22 The panel in Beer II, supra note 12, may seem to offer a way around the difficulty. Explaining why a New York tax law which discriminated explicitly against Canadian beer was not saved by the fact that it also discriminated against beer from the rest of the United States, the panel said, 'the national treatment provisions require contracting parties to accord to imported products treatment no less favourable than that accorded to any [emphasis added] like domestic product ... Article III consequently requires treatment of imported products no less favourable than that accorded to the most-favoured domestic products' (para. 5.17). Unfortunately, the panel's paraphrase of Article III adds a crucial word. The 'any' highlighted above does not appear in the text. And if, for example, we read in the word 'some' instead of 'any', then the conclusion would be that Article III requires only treatment of foreign goods no less lavourable than that accorded to the least-favoured domestic products. Rewriting the text is unacceptable. (Nevertheless, on the facts, the result is correct.) 
discrimination, what 'like' standardly means is something like 'not differing in any way which justifies different treatment'. ${ }^{23}$

It is worth recalling specifically what the Vienna Convention on the Law of Treaties says about ordinary meaning. 'A treaty shall be interpreted in good faith in accordance with the ordinary meaning to be given to the terms of the treaty in their context and in the light of its object and purpose' (Article XXXI). There is some tendency to view this as a staged inquiry: if there is a disputed term, first look for the ordinary meaning, and if that produces no clear answer, seek help from the context and the purpose of the treaty. But words generally do not have any contextindependent 'ordinary meaning', and the Convention could hardly be clearer in rejecting such a conception of ordinary meaning. The Convention refers to the ordinary meaning to be given to the terms ... in their context'. Ordinary meaning is treated as only assignable within a context. The context informs the inquiry from the beginning.

It may seem that we are too dismissive of physical similarity. It is tempting to concede at least that if two products strike one initially as physically quite different, then it will take a story to explain why they are 'like', and if they strike one initially as physically quite similar, then it will take a story to explain why they are 'unlike'. But even this concedes too much to the notion that there is an initial context-independent judgment of degree of likeness (or even of physical similarity), which is then modifiable by closer attention to context; whereas the truth is that one's very first judgment is already determined by what one already knows and what question one has in mind. This much is true: whatever the context, products which are more physically similar will, other things being equal, be more likely to be 'like'. But this is too general to help with any concrete question (and notice it does not imply that physical identity entails 'likeness').

If we assign 'like' its ordinary meaning in context, 'not differing in any respect relevant to an actual non-protectionist regulatory policy', then physically identical products that differ only in their processing histories may be 'unlike', because the processing differences may be relevant to such a policy. If one is not primed by thinking about tuna/dolphin problems or micro-brewery tax-exemptions, or whatever, one could easily read Article III (or even write it) without ever thinking about process-based measures. That does not alter the fact that the ordinary meaning of 'like' in this context is such that process-based distinctions can be relevant to

23 This seems completely clear in connection with Article III(1) and III(4). The situation is more complicated in IIT(2), since the context of 'like' includes the puzzling difference between the first and second sentences (about which we shall have more to say below). But even herc, the most obvious difference between the two sentences (once the second is supplemented by the interpretive Note) is in regard to the degree of similarity contemplated, which translates into the degree of difference in taxation which is justifiable, not into any exclusion of considerations other than physical constitution.

As the panel says in Beer II, supra note 12, '[I]t is essential that [determinations of "likeness"] ... be made not only in the light of such criteria as the products' physical characteristics, but also in the light of the purpose of Article III, which is to ensure that internal taxes and regulations "not be applied to imported or domestic products so as to afford protection to domestic production".' (para. 5.71). We shall explain below why the Japan Alcohol AB ruling does not represent a retreat from this position. 
'likeness', ${ }^{24}$ At this point the opponent of process measures might concede our claim. about the meaning of 'like' but argue that physical identity is sufficient for 'likeness' because differences in processing history alone cannot justify different regulation at the consumption stage. It may seem that the consumption of physically identical products which differ only in their processing history cannot have different consequences; but in fact it can. In the normal course of economic activity, when a product is sold to the consumer, the seller will tend to replenish his supply from the same source. That means that the purchase of a can of dolphin-safe tuna tends to encourage the subsequent production of dolphin-safe tuna, while the purchase of a can of dolphin-unsafe tuna tends to encourage the subsequent production of dolphin-unsafe tuna. This is not the invariable result, but it is quite general enough so that we can say the sale of dolphin-safe and dolphin-unsafe tuna have different consequences, which can justify different regulation, despite the fact that the tuna itself is indistinguishable. The opponent of process-based measures might now claim that the regulatory policies which are promoted by process-based measures are inadmissible, at least as applied to foreign products, because the importing country simply has no business caring about processing behaviour which goes on elsewhere and leaves no mark on the product itself. We shall confront this argument directly in section 3C. For the present, we merely observe that there is nothing in the text of Article III (or Article I, which also talks about 'like product[s]') to suggest that any regulatory policies are inadmissible except favouritism between nations or protectionism.

\section{The Jurisprudence}

Let us turn now to the jurisprudence on 'like products' as it relates to the product/process distinction. We shall discuss aspects of a number of cases, but it is worth emphasizing at the outset that there is only one adopted report invalidating an origin-neutral process measure, United States - Measures Affecting Alcoholic and Malt Beverages; and the result in that case can be explained by the fact that the United States offered essentially no policy justification for a law that had a disparate impact on foreign brewers.

(1) Often the beginning point for the case that process-based measures cannot be justified under the GATT is taken to be the early Belgian Family Allowances ${ }^{25}$ case. In that case, a panel considered a Belgian measure that provided an exemption from certain charges on imports purchased by Belgian governmental entities, where the imports originated from a country that was deemed to have a system of family allowances that met a particular set of criteria. In this case, the panel found a violation of Article I most-favoured-nation treatment and 'possibly' an Article III violation. While the panel, typical of this era of GATT decisions, did not give reasons for its

24 If the fact that the language of Article III does not immediately call to mind the issue of process-based measures had any significance at all (which we deny), it would mean that such measures were not covered by III; but we have already seen that that would create a huge and unacceptable gap in treaty coverage. (Text at note 17 supra.)

25 BISD 1 (1953) 59 , 
judgment but merely asserted the Belgian scheme was 'based on a concept which was difficult to reconcile with the spirit of the General Agreement', it is not difficult to find violations of Articles I and III in this instance, since the Belgian measures treated products differently based upon the country of origin. This case is therefore completely unrevealing about the approach to origin-neutral process-based measures under Article III,

(2) United States - Measures Affecting Alcoholic and Malt Beverages (Beer II) is the only instance in which an origin-neutral process measure has been found to violate Article III. The panel invalidated a Minnesota tax credit for micro-breweries, even though it assumed for purposes of argument that the tax credit was available to foreign brewers as well as domestic. They wrote, "The Panel considered that beer produced by large breweries is not unlike beer produced by small breweries. Indeed, the United States did not assert that the size of the breweries affected the nature of the beer produced or otherwise affected beer as a product.' 'The reference to 'the nature of the beer produced' might suggest that likeness is determined by the physical constitution of the product. But then how are we to understand the further reference to 'otherwise affect[ing] beer as a product'? Is this mere repetition, or does it mean what it appears to mean, that things other than the physical constitution of the beer may be relevant to the definition of 'beer as a product'? This is left unclear.

The result, however, is easy to understand. The United States made no serious effort to expound a regulatory policy other than to claim the tax credit was a subsidy for micro-breweries allowed by section $I I I(8)$ (b) (which incidentally almost concedes that the scheme is discriminatory in intent, since $8(\mathrm{~b})$ is about discriminatory subsidies). The panel held that the tax credit could not be justified as a subsidy under 8 (b) because it was not a 'payment'. With the subsidy argument out of the way, the United States was left with nothing but the bare expression of an idiosyncratic and not-intuitivelycompelling preference for one sort of producer, which will rarely if ever be enough to justify a law with significant disparate impact.

(3) The other case in which a panel invalidated an origin-neutral process measure on the basis of the product/process distinction was the unadopted report in United States Taxes on Automobiles, in regard to origin-neutral aspects of the fleet-accounting rules. This report adds nothing to the arguments we have considered except the suggestion that process-based measures somehow constitute a special threat to the integrity of tariff bindings. Of course one of the functions of Article III is to protect the value of tariff bindings, but that gives no reason to treat process-based measures as specially dangerous. (a) It seems peculiar to condemn the whole class of process-based measures, many of which may operate on goods where there are no bindings at all. (b) Even where there are bindings, a commitment to limit the tariff on tuna, say, does not, absent special circumstances, seem like a commitment not to regulate on the basis of a new, non-protectionist policy to reduce dolphin-mortality when that problem comes to the legislators' attention. (No more than a tariff binding on beef would represent a commitment not to ban hormone-treated beef if it were discovered to be dangerous, or came to be plausibly thought so by the importing country.) (c) If there are special circumstances where the adoption and even-handed application of such a new policy 
does seem unfair because it disappoints a definite expectation based on a concession like a tariff binding, there is a specific provision of the treaty for dealing with such cases, Article XXIII(1)(b) on non-violation impairment of benefits.

(4) The case that merits closest attention, even though it does not involve a process-based distinction, is the decision of the Appellate Body in Japanese Alcohol. Our view about the meaning of 'likeness' obviously commits us to the proposition that the 'aims' and 'effects' of a regulation are important to deciding whether it violates Article III. (That is not to say we are committed to 'the aims and effects test', since there is unclarity about just what that test is.) It is widely believed that in Japanese Alcohol the Appellate Body rejected the aims and effects test; and it may seem that they therefore rejected our view of 'likeness'; and it may seem that in doing that they implicitly endorsed the product/process distinction. But all of these claims are either false or much overstated,

Japanese Alcohol involved claims under Article III(2), which concerns internal taxation, as opposed to III(4), which deals with laws, regulations, and requirements. The structure of Article III(2), as interpreted by the Appellate Body, is different from that of Article III(4). Article III(2) contains two different standards for National Treatment. Under the first sentence of III(2), imports must be taxed identically to 'like' domestic products. Under the second sentence of III(2), which is read in conjunction with the Note Ad Article III, imports must not be taxed dissimilarly from directly competitive or substitutable domestic products so as to afford protection to domestic production. The final element of this test ('so as to afford protection to domestic production') is grounded in the fact that $\Pi(2)$, second sentence, contains a specific reference to Article III(1), in which the general anti-protectionist policy underlying the National Treatment obligation of Article III is announced. III(2), first sentence, contains no such specific reference back to III(1). We shall comment presently on the significance of this difference in structure between the two sentences of III(2),

First, however, let us consider how the Appellate Body applies the 'affords protection' standard in III(2), second sentence. This is the point in the report where it may seem that the Appellate Body rejects consideration of 'aims and effects'. What the Appellate Body says is that whether the tax scheme affords protection 'is not an issue of intent. It is not necessary for a panel to sort through the many reasons legislators and regulators often have for what they do and weigh the relative significance of those reasons to establish legislative or regulatory intent. If the measure is applied to imported or domestic products so as to afford protection to domestic production, then it does not matter that there may not have been any desire to engage in protectionism in the minds of the legislators or the regulators who imposed the measure.' Now, in general terms, what the Appellate Body is doing here is rejecting an argument made by Japan, that the panel is legally required to consider 'aims and effects' before finding that a measure 'affords protection' (p. 3). The Appellate Body appears to be interpreting Japan's claim as that only evidence of subjective protectionist purpose is sulficient to find that the measure 'affords protection'. As against this, the Appellate Body can be interpreted, at a minimum, as saying that in order to find that a measure 'affords protection', it is not necessary that there be a 'smoking gun' in the form of an 
explicit assertion of protectionist purpose by some legislator or governmental official. But this proposition is entirely consistent with two other propositions: (1) that the question of whether a measure 'affords protection' is still best understood as a question about what we might call the 'objective purpose' of the measure, that is, the best understanding of what the measure is about considering its provisions, structure, and political and historical context; and (2) that evidence of 'subjective purpose' in the form of ministerial or legislative statements is highly relevant on the question of 'affording protection', when such evidence exists. These further propositions obviously leave a place for appropriate attention to 'aims and effects'; and in fact the Appellate Body seems to be committed to both of these propositions.

As to the first proposition, we agree with Robert Hudec that the Appellate Body's further discussion in Japanese Alcohol of how the inquiry into 'protective application' should proceed sounds like nothing so much as an inquiry into 'objective purpose'. ${ }^{26}$ Thus, the AB suggests: '[The inquiry] requires a comprehensive and objective analysis of the structure and application of the measure... We believe it is possible to examine objectively the underlying criteria used in a particular tax measure, its structure, and its overall application to ascertain whether it is applied in a way that affords protection to domestic products. [paragraph break omitted] Although it is true that the aim of a measure may not be easily ascertained, nevertheless its protective application can most often be discerned from the design, the architecture, and the revealing structure of a measure. ${ }^{27}$ And so on. 'Protective application' seems very much a matter of the best understanding of the apparent purpose, gleaned from objective evidence.

As to the second proposition, in the subsequent Canadian Periodicals case, the Appellate Body made extensive use of ministerial statements and legislative history concerning the purpose of the scheme as a whole to establish that the application of that scheme afforded protection to domestic magazines. ${ }^{28}$ It may seem that consideration of such 'subjective intent' is problematic in an international dispute settlement regime that must consider regulations issuing from a multitude of very different political processes. But we see no objection to the use of evidence of subjective intent, provided two principles are kept in mind, one pointing in each direction. First, as the Appellate Body insisted in Japanese Alcohol, there does not have to be a 'smoking gun'. It is perfectly possible to find that a measure is protectionist on the basis of its structure, its effects, the intuitive compellingness of the distinctions it draws, whether the claimed regulatory goal is shared with other legal systems or multilateral regimes, the measure's timing, and so on, without any reference to explicit statements of purpose (and even in the face of explicit assertions of innocent purpose). Second, all evidence must be carefully evaluated. (Smoking guns do not always prove the existence of a crime.) Not every statement by a government official of a desire to

26 Hudec, 'GATT/WTO Constraints on National Regulation: Requiem for an "Aims and Effects" 'Test', 32 The International Lawyer (1998) 619 at 631.

27 Japan - Taxes on Alcoholic Beverages, Report of the Appellate Body, WT/DS8, 10,11/AB/R, 4 October 1996. at 27.

28 Canada - Certain Measures Concerning Periodicals, Report of the Appellate Body, WT/DS31/AB/R, 30 June 1997 , at $15-16$. 
'protect' some local interest reveals an intention to protect locals at the expense of foreign competitors (which is 'protectionism'). Furthermore, a statement by a single legislator or official may not reflect the intentions of his colleagues. Nor is a measure protectionist just because producers who would benefit from it are among those who supported it. ${ }^{29}$ In sum, we should neither insist on explicit evidence of bad subjective intent, nor overreact to any and every bare suggestion of such an intent that an open and robust political process may throw up.

So, in its discussion of 'affording protection', the Appellate Body in Japanese Alcohol may or may not have rejected 'the aims and effects test', but it clearly did not reject consideration of aims and effects. It is worth noting also that the Appellate Body did not repeat an argument for rejecting the aims and effects test which was made by the panel below, and which has some general currency, namely, the argument that an 'aims and effects' test would make Article XX inutile. The argument is misguided. It is true that if we consider regulatory purpose, then there will be no further decision to make under Article XX in those cases where we have already decided in applying Article III that a facially neutral measure with disparate impact serves no valid regulatory purpose. But Article XX will still have a role to play in cases where the violation of Article III is established by facial (country-based) discrimination, or in cases coming from Article XI or other Articles. It is a general principle of treaty interpretation that every clause should have a function, but it is not a general principle of interpretation that every clause should require a new substantive decision in every case where it is formally relevant. So consideration of 'aims and effects' creates no problem in conjunction with Article XX. Indeed, even on the Appellate Body's formally stated view, before a measure can be found to violate Article III(2), second sentence, it must be found to operate 'so as to afford protection', which seems to leave no more room for a real question under Article XX than would a finding of violation based on an 'aims and effects' test.

Even if 'aims and effects' are relevant to the question about 'affording protection' under Article III(2), second sentence, the Appellate Body's report might suggest to an unwary reader that they are not relevant under III(2), first sentence. We have noted that there is a textual difference between the sentences. The second sentence refers explicitly to the anti-protectionist policy announced in III(1), while the first sentence does not. The Appellate Body insists that this textual difference must be reflected in the way III(1) informs III(2), first sentence, and III(2), second sentence; and it is easy to read them as suggesting that the difference is that the anti-protectionist policy of Article III(1) has a role to play in the application of III(2), second sentence, but not in the application of III(2), first sentence. But that is not exactly what the Appellate Body says.

Again, let us start with III(2), second sentence. What the Appellate Body says about III(2), second sentence, is that there is a required separate step of looking to see whether a tax 'affords protection to domestic production'. Even after it has been decided that the tax treats 'directly competitive or substitutable products' 'not

29 See the discussion of 'protectionism' in Pert 3D. 
similarly', there is the third step to go through. The Appellate Body does not explain why the separate third step is necessary, but an example will make it clear. Imagine a consumer product which comes in a polluting version and a non-polluting version. (The pollution from the polluting version is caused by the consumer's use of the product, not the manufacturing process.) The two versions cost essentially the same to make; they function equally well from the consumer's point of view; and the pollution is externalized on people other than the consumer, so the selfish consumer does not care which version he gets. Suppose that Utopia tries to compel internalization of the costs of pollution by imposing a substantial tax on the polluting version of the product. And suppose finally that this tax falls disproportionately on imports from Barataria, whose producers by and large make the polluting version. We assume the products are sufficiently different in their physical constitution so they are not 'like' under III(2), first sentence. Does the tax violate III(2), second sentence? The goods are 'directly competitive or substitutable' (consumers are indifferent), and we can assume the tax is large enough so they are 'not similarly taxed'. If there were no further requirement that the measure be contrary to the principle of III(1), the tax would be a violation. But the tax is obviously a sensible, non-protectionist measure. It should not be a violation, and the reason is precisely that it is not applied 'so as to afford protection to domestic production'. So we need the third step to get the right result. The reason we need the third step is that 'directly competitive or substitutable' is a very different sort of concept from 'like', which is the parallel operative concept in III(2), first sentence, Comparing the texts of III(2), first sentence, and III(2), second sentence, the thing that first strikes one is that 'directly competitive or substitutable' seems to require a lesser degree of similarity than 'like'. But there is another crucial difference: 'directly competitive or substitutable' restricts the dimensions of comparison to one very particular dimension, utility to the purchaser, which means that products will be judged equivalent if they are similar on that dimension, regardless of how different they may be in other undeniably important respects like causation of externalities.

Returning now to III(2), first sentence, we do not need to insist on a separate step under this sentence in order to consider the anti-protectionist policy of III(1), for the simple reason that the word 'like', unlike the phrase 'directly competitive or substitutable' can itself be interpreted in light of that policy, 'Like', in its ordinary meaning in context, is open ended. It does not restrict our attention to any single dimension of comparison. There would be no difficulty, for example, in saying that the two versions of the consumer product in the previous paragraph were 'unlike', however minute was the physical difference that resulted in their (substantially) different consequences when consumed. So, we can have a difference between III(2), first sentence, and $\operatorname{III}(2)$, second sentence, as the Appellate Body says, without insisting that III(2), first sentence, be applied without reference to the policy of III(1). Article III(2), first sentence, can and should be interpreted with reference to the policy of III(1), but we do not need a separate step to do it as we do under III(2), second sentence. (This issue of whether there must be a separate step is what the Appellate Body focuses 
on again when it revisits in Bananas ${ }^{30}$ the question about the role of III(1), this time in connection with III(4). III(4) is like III(2), first sentence, both in using the word 'like' and in making no explicit reference to III(1). The Appellate Body in Bananas reads the Panel as having said IIr(4) requires a separate step of looking to III(1), and it says that is error. What we should conclude from this is not that III(4) must be interpreted without reference to the policy of III(1), but rather that III(4) should be interpreted in light of the policy of III(1) without the need for a separate step.)

We are suggesting that 'like', whether in III(2), first sentence, or in III(4), should be read in light of the anti-protectionist policy of III(1). This is consistent with the claim that there must be a difference between $\operatorname{III}(2)$, first sentence, and $\operatorname{III}(2)$, second sentence, but is it consistent with what the Appellate Body in Japanese Alcohol says about the meaning of 'like' in III(2), first sentence, itself? Yes, it is. The Appellate Body emphasizes that because there are two sentences in III(2), which must both be significant, 'like' in III(2), first sentence, must connote a very high degree of similarity. (Incidentally, there is a very important difference between the context of 'like' in III(2), first sentence, and in the unitary III(4), ${ }^{31}$ We shall not pursue that.) But as to the question of just how high a degree of similarity, and as to the relevant dimensions of the comparison, the Appellate Body merely emphasizes the contextual, discretionary nature of the judgment. It memorably compares the concept of 'likeness' to an accordion, which may be stretched wide or squeezed tight as the case requires. Furthermore, it says nothing to suggest that regulatory purpose could not be relevant to the determination of likeness. It provides a list of factors such as similarity of end uses, and consumer preferences, along with the products' 'properties, nature, and quality', which it stresses is open ended and which has to be applied in context. This list admittedly does not contain explicitly the notion of regulatory purpose. However, the Appellate Body says that which factors an adjudicator should consider in each case will depend on the case - in the context of taxation of vodka and shochu, Japan simply did not propose, on appeal, that the distinction in the scheme should be upheld because it made sense in terms of the scheme's regulatory purpose.

So, in every aspect of the case, the Appellate Body allowed itself and dispute panels the flexibility to consider 'aims' and 'effects'. And rightly so - sensible consideration of aims and effects is essential to identifying protectionism, and limiting protectionism is what the treaty is about. As we shall explain in Part 3, mechanical rules are no substitute for judgment in this area. If the Appellate Body enforced any test that truly foreclosed consideration of aims and effects, it would do so only at a cost to its own legitimacy and to the legitimacy of the treaty, ${ }^{32}$

30 European Communities - Regime for the Importation, Sale and Distribution of Bananas, Report of the Appellate Body, WT/DS27/AB/R, pares 515-516.

31 III(4) has two sentences, but they are not separate requirements as in III(2). The second sentence of III(4) is an interpretive direction that limits the preceding requirement.

32 Again, cf. Hudec, supra note 26. 


\section{Conceptual Issues and Policy Arguments about the Product/Process Distinction}

Despite the lack of jurisprudential basis in the GATT for treating regulations based on the intrinsic characteristics of products differently from regulations based on aspects of the production process, the intuition that process-based measures are somehow specially problematic is widely shared. Thus, to dispose fully of the product/process distinction, we must go beyond an analysis of the existing legal text and jurisprudence of the GATT and attempt to understand and address this intuition. That is the task for this second part of the paper. In fact, the intuition has a number of different roots, which is one of the reasons it is so tenacious. We shall have to inspect it from a number of angles.

\section{A Distinguishing 'Country-based' Restrictions}

It seems that one reason people view process-based restrictions as specially problematic is that they conflate them with what we have called 'country-based' restrictions. As we explained previously, we are defending process-based restrictions, which are origin-neutral, not country-based restrictions, which make explicit reference to the national origin (or less often, and in other contexts, the destination) of products. Because they discriminate explicitly by reference to nationality, countrybased restrictions violate Article I, or III, or XI, as the case may be, and are therefore prima facie violations of GATT. (They may be justified under Article XX, but that is no part of our concern in this paper, ${ }^{33}$ ) Process-based restrictions seem quite obviously different.

The practical difference between 'process-based' and 'country-based' restrictions is clear. Suppose that Barataria is a country that allows the use of turtle-unfriendly shrimp nets, and imagine a Baratarian fisherman, Luiz, who nonetheless uses turtle-friendly nets, If the importing country imposes a process-based restriction, then Luiz's shrimp comes in. If, on the other hand, the importing country imposes a country-based restriction, then Luiz's shrimp is excluded. ${ }^{34}$ In addition, it is clear from the terms of Articles I and III that what these articles are centrally concerned to discipline is country-based discrimination. (Article XI as well, if we reflect that import restrictions which are not extensions of internal regulatory schemes distinguish

33 Notice that among the 'country-based' restrictions which might be adopted for the purpose of discouraging dolphin-unsafe tuna fishing we might find not only prohibitions on the import of tuna from countries that allow dolphin-unsafe fishing, but also broader prohibitions on the import of other products from the same countries, as well as intermediary-country restrictions, We shall discuss only the case of tuna-excluding restrictions limited to the target country - broader restrictions being obviously a fortiori cascs.

34 To be sure, in some circumstances, the country-based restriction and the process-based restriction may come to the same thing in practice. For example, if Barataria allows turtle-unfriendly shrimp nets and every Baratarian producer chooses to use the turtle-unficiendly nets, then the effect of the country-based restriction and the process-based restriction will be the same. No Baratarian producer will be able to sell in the importing country's market. But of course two regimes that have the same effects in some circumstances may have different effects in other circumstances, and may be very different in principle. 
between goods on the basis of whether they are local or foreign.) Despite all of this, many people still seem to regard process-based measures as guilty by association. Why might this be?

To some, it may seem that what is wrong with country-based restrictions is that they attempt to coerce other countries into changing their policies, or that they are extra-territorial, or that they are protectionist; and it may then seem that processbased restrictions are essentially similar in the relevant respects even if they are somewhat milder in application. In fact, process-based restrictions are very different from country-based restrictions with respect to all of these arguments, but the explanation must wait for the full discussion of extra-territoriality in $3 \mathrm{C}$ and protectionism in 3D. In more general terms, it may seem that process-based and country-based measures have sufficiently similar economic effects so that they should stand or fall together. This argument we can dispose of now.

Why are country-based measures presumptively illegal (that is, illegal unless they are justified under Article XX)? The primary answer is that distinctions of nationality are irrelevant to economic efficiency. Products which differ only in their nationality should have the same competitive opportunities. In contrast, differences in processing may be very relevant to efficiency, ${ }^{35}$ But in a very impressive defence of process-based restrictions, and country-based restrictions, and, indeed, trade sanctions generally, Howard Chang has argued (1) that country-based restrictions (limited to the relevant product) may be necessary to achieve the goals that countries try to achieve by process-based restrictions, and (2) that such country-based restrictions (like processbased restrictions but unlike broader trade sanctions) will involve no efficiency costs. ${ }^{36}$ These claims certainly tend to call into question the economic significance of the process/country distinction, so we want to explain briefly why the first claim is less significant than it seems and the second claim is false. We should say that we are fully in sympathy with what we take to be the overall object of Chang's article, which is to argue that country-based restrictions and even trade sanctions are all eligible for justification under Article XX (and that they do not forfeit that eligibility just because

A country-based restriction and a process-based restriction will necessarily have the same consequences if (improbably) Barataria requires its producers to use turtle-unfriendly nets (and Baratarian shrimpers are law-abiding). But this should make no difference to the legality of the process-based restriction. If the process-based restriction is otherwise justificd (as we are in the process of arguing that it may be), then the justification is not affected by the fact that Barataria has a conflicting policy. Barataria cannot turn an otherwise justifiable regulatory scheme into a GATT violation just by requiring its producers to violate it. There is no country-based discrimination by the importing country, even if Barataria decides, as a country, that none of its producers shall be allowed to comply with the importing country's process-based requirements. It might be suggested that the possibility of such an incompatible requirement by Barataria means that process-based restrictions are specially likely to segment markets. That claim we discuss below in 3D.

35 We have noted in Part 2 that restrictions at the consumption stage can affect what processes are used. See also the discussion in $3 \mathrm{~B}$ infra.

36 See If. Chang, 'An Economic Analysis of Trade Measures to Protect the Global Environment', 83 Georgetown Law Journal (1995) 4. 
they concern themselves with environmental effects outside the boundaries of the importing country, or because, in particular cases, they can be effective only by changing the policy of some other country). But our concern in this paper is with the prior question of what sorts of measure require justification under Article XX - what is a prima facie violation? It is in respect of that question that process-based and country-based measures are different, in ways Chang underestimates.

Chang points out that if what the importing country wants is that its shrimp consumption should not encourage turtle mortality, then it cannot be sure of achieving this just by excluding turtle-unfriendly shrimp (shrimp which was itself caught with turtle-unfriendly techniques). If the importing country, call it Utopia, takes turtle-friendly shrimp from a country, Barataria, that allows turtle-unfriendly fishing, it may be that what will happen is that turtle-friendly shrimp which was previously being sold to some other less turtle-conscious country is diverted to Utopia, and the demand in the second, less turtle-conscious consuming country is supplied with new production of turtle-unfriendly shrimp. By this route, Utopia's consumption of turtle-friendly shrimp can encourage turtle-unfriendly shrimp fishing. To avoid this, Utopia must exclude not just turtle-unfriendly shrimp from Barataria but all shrimp from Barataria, so long as Barataria allows turtle-hostile fishing. ${ }^{37}$

All of this, however, depends on assumptions that are more problematic than Chang realizes. Barataria will not be able to divert existing production of turtlefriendly shrimp to Utopia and make up the resulting deficit elsewhere with turtle-unfriendly shrimp unless the diverted turtle-friendly shrimp was being sold in a market that is prepared to accept turtle-unfriendly shrimp. And this requires that the turtle-friendly shrimp in question was not more expensive than the turtle-unfriendly shrimp. But generally speaking, turtle-friendly shrimp is more expensive to produce than turtle-unfriendly shrimp, else the whole problem would not exist in anything like its present form. There may indeed be some turtle-friendly shrimp which can compete with turtle-unfriendly shrimp in a market where there is no premium for turtlefriendliness - either because the producers themselves are turtle-friendly and are prepared to absorb the extra cost of turtle-friendly production, or because there are some infra-marginal opportunities for inexpensive turtle-friendly shrimp fishing, for example, in fishing grounds where there are no turtles. But the relevant stocks must be limited.

And there is a further precondition for diversion to occur. Not only must there be turtle-friendly shrimp cheap enough to compete with turtle-unfriendly shrimp in markets where turtle-friendliness commands no premium; but also there must not previously have been markets where turtle-friendly shrimp commanded a premium in which the total effective demand was at least as great as the quantity of such 'cheap' turtle-friendly shrimp available. The reason for this second condition is that even turtle-friendly shrimp which was produced cheaply enough to compete head-to-head with turtle-unfriendly shrimp would earn rent by being sold in a market where a premium was paid for turtle-friendliness, and so would be sold in that market if

37 The argument can be extended to intermediary-country embargoes, which we shall ignore. 
demand existed. In sum, for turtle-friendly production to be diverted and replaced by turtle-unfriendly production, there must be a supply of inexpensively produced turtle-friendly shrimp in excess of the previously effective demand for turtle-friendly shrimp. That there should be such an excess that is large enough to be really significant seems quite unlikely.

The fact that there is not likely to be much product-diversion for country-based measures to prevent would matter less if country-based measures were no threat to efficiency. Chang says that 'From the perspective of global economic efficiency, there is no reason to object to process standards and other direct trade measures [which includes country-based restrictions], as long as they actually promote genuine environmental interests and are in fact justified by the value attached to these interests. ${ }^{38}$ Now taken literally, this is tautological - if the measures are justified by the value of their consequences, there is no reason to object to them. But what Chang appears to mean is that as long as they are not adopted with protectionist motives, they are justified, because they will have no efficiency costs. This is over-optimistic.

Chang is right that the importing country's preference for turtle-preservation is something that must be taken into account in thinking about what efficiency requires (that is a point we shall return to and develop ourselves in section 3D below); and he is right that in the presence of this preference, process-based restrictions merely compel the (partial) internalization of an externality occasioned by turtle-unfriendly shrimp production; and he is right that insofar as country-based restrictions merely prevent the diversion of existing turtle-friendly shrimp and replacement with increased turtle-unfriendly production, they have similar pro-efficiency effects. Despite all that, country-based restrictions are very likely to have efficiency costs. Consider for example a country-based restriction imposed by Utopia. This may prevent Barataria from diverting cheap turtle-friendly shrimp to Utopia and increasing its production of turtle-unfriendly shrimp. So far, so good. But it will also prevent Barataria from engaging in new production of expensive turtle-friendly shrimp for the Utopian market, even though Barataria may be the cheapest producer of expensive turtle-friendly shrimp. Hence, country-based restrictions can cause misallocation in the production of expensive turtle-friendly shrimp. Process-based restrictions and country-based restrictions really are different, not just in form, but in economic effect.

\section{B Two Misconceptions about Consequences, of Consumption and of Labelling Requirements}

We have already encountered in Part 2 the argument that differences in processing history cannot possibly justify different regulation at the consumption stage, because the consequences of the consumption of a product depend only on the product's intrinsic properties at the point of sale and not on how it was manufactured. But as we have pointed out, this is not so. In the normal course of economic activity, when a product is sold to the consumer, the seller will tend to replenish his supply from the

38 Chang 1995, supra note 36 , at 2185. 
same source. That means that the purchase of a can of dolphin-safe tuna tends to encourage the subsequent production of dolphin-safe tuna (with the attendant consequences of that subsequent production), while the purchase of a can of dolphin-unsafe tuna tends to encourage the subsequent production of dolphin-unsafe tuna (with the attendant consequences of that subsequent production). This is not the invariable result, but it is quite general enough so that we can say that the sale of dolphin-safe and dolphin-unsafe tuna have different consequences for the nature of future production. Because the consequence relation is transitive, the consequences of the further use of the process which the purchase causes are also consequences of the purchase. So, if a process has objectionable consequences, so does the purchase of tuna produced by that process. The purchase of dolphin-safe and dolphin-unsafe tuna therefore have different consequences, which can justify different regulation, even though the tuna itself is indistinguishable. (As we said before, the opponent of process-based measures might now claim that the regulatory policies which are promoted by process-based measures are inadmissible, at least as applied to foreign products, because the importing country simply has no business caring about processing behaviour. which goes on elsewhere and leaves no mark on the product itself. We shall confront this argument directly in section 3C. What we have disposed of is the logical claim that distinguishing between products which are identical at the consumption stage cannot be justified by reference to consequences.)

A different argument (but with a similar intuitive feel) which is regularly levelled against process-based restrictions is that they are disproportionate, and therefore illegal, because the same results could be achieved by (less intrusive) labelling requirements. But this is not true, Or more accurately, whether it is true depends on the nature of people's concerns. If all that anyone in the importing country cares about is that her own purchase of shrimp should not encourage the killing of turtles, and if the extra cost of buying turtle-friendly shrimp is no serious object, then indeed labelling requirements solve the problem. People who care about turtles (in this limited way) can just buy turtle-friendly shrimp. The situation is slightly more complicated if the extra cost of turtle-friendly shrimp matters. It may be that some consumer is willing to pay that extra cost if and only if she knows that the turtles will thereby be saved, which depends not just on what she does, but on what others do as well. Here the consumer needs information about collective behaviour, which is not provided just by labelling.

But the most serious problem is further along. It may be that the people who care about turtles do not eat shrimp at all (and conversely, the people who eat shrimp do not care about turtles). Now the consumers of turtle-unfriendly shrimp are imposing an externality (the death of turtles) on a completely distinct group. It is to prevent this externality (or, as the friends of the turtles may view it, this immorality) that the process-based restriction is imposed. And it is perfectly clear that labelling will not solve this problem. (No one suggests that a country that wants to prevent the import of assault weapons, or leaded gasoline, or pornography must content itself with labelling requirements.) Perhaps some people who make the 'labelling' argument against process-based restrictions truly believe that a government has no business preventing 
its citizens from engaging in what a majority regard as immoral behaviour, and no business protecting the majority from behaviour by their compatriots that disappoints their preferences about events that have no effect on their physical or financial welfare. But there has never been a government that recognized such a limitation, and it is not remotely plausible to suppose that GATT incorporates such a principle. (Lest it seem that we are being legalistic, we should add that we also do not think such a principle is defensible in normative political philosophy - but that is definitely another matter.) Labelling is not an adequate substitute for process-based restrictions.

\section{Extra-territoriality and Related Arguments}

We turn now to the argument that process-based restrictions are objectionably extra-territorial. If we are talking about extra-territoriality in its core sense, this is simply false. Process-based restrictions do not directly regulate any behaviour occurring outside the border. To be sure, whether a particular product may be imported depends on what has previously happened to it outside the border. But nothing that has happened outside the border attracts, by itself', any criminal or civil sanction. Foreign producers can use whatever processes they want, and use them with impunity. The only thing they cannot do is bring products produced with certain processes into the country. ${ }^{39}$

Sometimes, however, 'extra-territoriality' is used loosely to denote any attempt to influence conduct in a foreign country that falls under the regulatory jurisdiction of that country. This is the sense in which process-based measures may seem to be extra-territorial. In response, we observe, first, that process-based measures may have policy rationales that do not depend on any expectation of influencing foreign conduct. And second, that even if such measures are meant to influence conduct abroad, there is no general rule or norm that makes all such attempts to influence illegitimate.

Why might a country impose a process-based import restriction? (1) The importing country may hope that foreign shrimp fishermen (continuing with that as our example) will be moved to use turtle-friendly nets in order to gain access to its market. It may be trying to change their fishing technique. (2) Even if it knows the foreign fishermen will not change their technique, it may still impose the process-based restriction in order to reduce the market demand originating within the importing country for turtle-unfriendly shrimp. It may hope to reduce the intensity of the foreign shrimpers' fishing and the attendant turtle mortality. (3) Even if the process-based restriction will not affect either the shrimpers' technique or the intensity of their activity - even it will not affect their behaviour at all - the importing country may

39 Of course, a country might attempt to reinforce its process-based import restrictions by trying to exercise jurisdiction directly over conduct outside its own territory. The United States migbt for example attempt to apply American environmental requirements to the production lacilities of firms outside the United States that are largely or entirely owned by American shareholders or have parent companies or head offices in the United States. Such actions do ratse issues about extra-territoriality under general international law, but the issues are obviously quite distinct from the issues raised by the process-based import restrictions themselves. 
still impose the restriction because it wants to have nothing to do with shrimp, the taking of which involved killing of an endangered species. Some people do not want to benefit from or be associated with what they regard as wickedness even if they are unable to prevent it. (4) A somewhat different sort of reason for the import restriction is that, assuming a similar restriction is already in place for domestic fishermen (which is a prerequisite for the legality of the import restriction), then the import restriction may be imposed in part to 'level the playing field'. This is the justification which suggests to many people that such restrictions are protectionist. We shall explain in 3D why the accusation of protectionism is misguided in this case (that is, why 'levelling the playing-field' is sometimes just what efficiency requires); but suffice it to say for now that the issue of protectionism is obviously quite different from the issue of extra-territoriality. So we shall ignore (4) for the moment.

The possibility of (3) above makes it clear that the importing country may have a justification for the import restriction which does not depend on influencing behaviour abroad. This adds confirmation that import restrictions are not in their essence extra-territorial. But suppose the importing country does hope to alter the behaviour of foreign fishermen. Why is that supposed to be inappropriate? It might be said that the importing country is trying to penalize, or at least to discourage, certain behaviour outside its territory. But the importing country would counter that it is not trying to penalize foreign use of turtle-unfriendly techniques, nor even, properly speaking, to discourage it. It is merely trying to avoid encouraging the use of such techniques by buying turtle-unfriendly shrimp. The importing country claims, reasonably, that it is entitled to take measures to ensure that its own consumption does not contribute to what it regards as a great evil.

It is often claimed that the import restrictions invade the sovereignty of the country to which the fishermen belong. It is said that their home country should decide how they shall be permitted to fish. But the importing country is saying nothing about how the fishermen may fish. That is indeed up to their home country. All the importing country says is that shrimp caught by a method it regards as improper, and which it forbids to its own fishermen, may not come into the country. (Incidentally, even the inducement which the importing country offers for changing fishing techniques is not likely to be inconsistent with the home country's views of what should be permitted to their fishermen. How many countries require their shrimp fishermen to use techniques which kill turtles?) If 'sovereignty' is the issue, one could as well say that to deny the importing country the right to exclude shrimp caught by a method it abhors would be an invasion of its sovereignty. Where does one get the idea that the sovereignty of the producing country authorizes it to say not only how its fishermen may fish, but also where in the rest of the world they may sell? Where does one get the idea that the sovereignty of the producing country allows it to prevent other countries from choosing not to contribute to turtle mortality by consuming turtle-unfriendly shrimp?

At this point the opponent of the restrictions is likely to respond, perhaps with some asperity, that one gets this idea from GATT. GATT gives the producing country a right of access to the importing country's market. But the question, of course, is about the terms of that right of access. We have seen already in Part 2 that neither the text of the 
treaty nor the jurisprudence create any special hurdles for process-based import restrictions. Even so, there is room in principle for the opponent of such restrictions to argue, on grounds of extra-territoriality or sovereignty, that the text should be construed to disfavour them. Part of interpreting any complex, fundamental treaty instrument is figuring out what we would expect it to say about questions it does not directly address, what it ought to say in light of its most general and fundamental purposes and presuppositions. ${ }^{40}$ But in the present case, the opponents' argument against process-based import restrictions moves in a circle. The opponent appeals to extra-territoriality and sovereignty to elucidate what GATT requires, but then at a crucial point, an ungrounded claim about what GATT requires is brought in to complete the argument from extra-territoriality and sovereignty,

To be sure, there is more going on here than just the logical failure of one particular argument. We have bumped up against the deepest divide between competing understandings of GATT (a divide which has nothing fundamentally to do with extra-territoriality). One view is that GATT creates a general right of market access, which right may be denied only for internationally certified reasons (where international certification might involve anything from inclusion in a multilateral treaty to substantive endorsement by a WTO dispute settlement tribunal). The other view is that GATT creates no such general right of access, but creates only a negative right that access shall not be denied by rules that discriminate between countries. (This obviously oversimplifies somewhat. Specific provisions of limited scope, in the form of reservations or treaty provisions, may modify either view, detracting from the general right of access, or authorizing some nationality-based discrimination, or adding some prohibitions beyond the prohibition against discrimination. Still, this sketch captures the opposition between the two large views which compete to set the background assumptions for interpretation.)

Our own view, of course, is the second. So far as its general purpose and structure are concerned, GATT creates only a negative right of non-discrimination. This is clearly the main thrust of the treaty text itself. And in a number of rulings the Appellate Body has reversed panel findings based on the notion that the GATT protects general expectations of open market access. ${ }^{41}$ The 'general right of access' view, with its constraints on non-protectionist policy justifications for trade restrictions, derogates much more from national sovereignty than does the 'nondiscrimination' view - and much more than it is plausible to think the signatories intended. The doctrine of in dubio mitius counsels against finding such a derogation without much clearer textual support. When critics are attacking the WTO as an

40 Thus, the rules of interpretation of the Vienna Convention on the Law of Treaties require interpretation in light of context and purpose. This, however, does not mean that assumptions about context and purpose can simply trump the meaning of the text or create new obligations not supported by its actual language. as the Appellate Body bas emphasized in a number of cases, including the recent Turtles case, supra note 2.

4) India - Patent Protection for Pharmaceutical and Agricultural Chemical Products, Report of the Appellate Body, WT/DS/50, 16 January 1998; European Communities - Customs Classification of Certain Computer Equipment (LAN case), Report of the Appellate Body, 1998, paras 8-82. 
insidious, incipient world government, it is all the more necessary for its supporters to remember it is just a treaty.

The difference between the two views of GATT (the 'general right-of-access' view and the 'non-discrimination' view) explains many more specific divergences of perception. It explains, for example, why opponents of process-based restrictions see them as 'coercive', while defenders see them as at most attempts to influence foreigners' behaviour by permissible, non-coercive means. Not all attempts to influence amount to coercion. Denying someone something they have a right to (such as market access, on the first view of GATT) is a way of coercing them; whereas merely choosing not to deal with them, when that violates no right (as on the second view of GATT), and especially when one thinks that to deal with them would be to involve oneself in wickedness, is not.

Incidentally, we are now in a position to see how country-based and process-based restrictions differ in respect of coercion and extra-territoriality. Country-based restrictions can reasonably be viewed as extra-territorial. Unless they are justified under Article XX, they are violations of GATT (because the treaty says so and because they are efficiency-threatening, nationality-based discrimination); because they are violations, where they cannot be justified under Article XX, they deny foreign firms a right of access; where they deny such a right, they might be viewed as coercive in some circumstances; and because they are an attempt to coerce foreign governments over whom the coercing state normally has no jurisdiction, they can be said to be extra-territorial (in a derivative sense, which depends on the existence of the independent illegality; thus, where they can be justified under Article XX, countrybased measures will themselves not be coercive, because Article XX in such cases circumscribes the legal right not to be subject to such action). This makes it clear, however, how process-based restrictions are different. They are not nationality-based discrimination; they are therefore not even prima facie violations; they deny no right; they are therefore not coercive; hence, they are not extra-territorial, and without any need of Article XX justification.

It may seem that we rely too heavily on the idea that a mode of influencing others' behaviour is 'coercive' only if it involves the denial of some independently-specified right. Even if this is the best understanding of the notion of coercion, people sometimes speak loosely of the 'coercion' inherent in process-based restrictions as a way of claiming that large and economically powerful countries have too much influence over what goes on in smaller, poorer ones. If this is a problem, it is not a problem specilic to process-based restrictions; it is true of product-based restrictions as well. Indeed, it would be true even if governments did not act at all - consumer preferences in large, rich countries influence profoundly what is produced in small, poor ones. That flows from the operation of the global market that supporters of trade liberalization endorse. Furthermore, the negotiated rules of multilateral trade themselves reflect these same power imbalances (consider the examples of 'TRIPs and services). Remember also that process-based restrictions do not operate only between rich importers and poor exporters - consider the disagreement between the European Union and the United States about genetically modified food. The 
international trading system implicates large issues of distributive justice, which we shall revisit briefly in 3D, but it should be clear that such issues are not sensibly addressed by a ban on process-based restrictions.

There is another version of the 'extra-territoriality' objection that we should take note of. We have argued that as long as the importing country regulates directly only behaviour within (or at) its borders, then it is not regulating extra-territorially even if its goal is to avoid encouraging behaviour beyond its borders. Many people object to this on the ground that if the effects which the importing country is ultimately concerned with (such as the death of turtles) occur outside its territory, then it has no interest in the matter. The focus now is not on the location of the behaviour which is the immediate subject of the regulation (i.e. importing), nor on the location of the processing behaviour of the producer, but on the location of the ultimate effects the importing country is concerned with. To this argument there are, as usual, a number ol answers.

For a start, we should remember that the vast majority of actual process-based import restrictions are aimed at preventing harm which is of undeniable concern to the importing country. Very often, for example, the disfavoured processing method affects a commons, whether transboundary (between the importing country and the producing country), or multi-country, or global. To say that something is a commons is to say that the degradation or destruction of the commons would have further untoward consequences in or for each of those countries. In the Turtles case, for example, we have tended to speak as if the importing country's only interest was a moral concern for the turtles or for the integrity of the environment. But turtles are an endangered species, whose disappearance might disrupt we know not what ecosystems and cause the loss of other species - and all of this might deprive humans, including the population of the importing country, of very valuable and useful knowledge. In other cases, processing methods may threaten global commons such as the ozone layer or the ability of the environment to absorb greenhouse gases. Or a processing method may threaten a local endangered species that moves between the producing country and the importing country. Commons aside, the disfavoured processing method, occurring outside the importing country, may cause damage inside it by creating pollution which is transported to the importing country by air currents or aquifers. And so on. There are many ways in which processing behaviour outside the importing country can have effects within it, and most process-based restrictions are aimed at least in part at such effects. There is no ground for a general presumption that process-based restrictions are purely 'extra-territorial' in their. ultimate concern.

But even if a restriction is aimed solely at preventing harm outside the territory of the importing country, that is not an objection. We can see this in either of two ways. First, we can point out that in other contexts most people would regard it as obvious that a country may properly have as its regulatory goal the avoidance of harm occurring outside its borders. No one would doubt that a country may forbid the local manufacture for export of a product it regards as abhorrent or dangerous. Similarly, no one would question the prohibition of a manufacturing process because it caused 
pollution in other countries. Indeed, there are established principles of international environmental law that oblige states to avoid causing such harm. ${ }^{42}$ Finally, a product-based restriction would raise no eyebrows even if it were imposed for the purpose of not encouraging certain production processes with objectionable effects occurring entirely in the producing countries - for example, a prohibition on the domestic sale of foie gras, whether imported or domestically produced.

Alternatively, if the opponent of process-based restrictions insists that a country has no legitimate interest in effects beyond its borders, we could concede that for purposes of argument. We would then insist that even if the physical effects of the disfavoured processing method occur entirely outside the importing country, the importing country may be concerned to avoid the moral discredit (in its own eyes) of causing or encouraging harm or wickedness - and the moral discredit occurs within the importing country, regardless of where the physical harm occurs. This is not our preferred way of analysing the issue, since it requires that we assign a physical location to an essentially non-physical effect. But one way or another, one must recognize that it is the country's business (if it chooses) to avoid encouraging or being associated with what it regards as harmful or wicked behaviour, regardless of where the physical effects are felt. The desire to keep one's hands clean, to not be associated with wickedness even if one cannot prevent it, is a sufficiently common and deeply-felt human motivation so that we cannot simply put it out of court.

There is an irony here worth pointing out. It is 'tough-minded' proponents of free trade, whose core argument is economic efficiency, who tend also to argue that a country has no legitimate interest in what goes on outside its borders. But these arguments do not cohere. From the point of view of economics, what we have been discussing as a moral interest of the importing country is just another preference, and there is no economic criterion for the 'legitimacy' of preferences. In particular, preferences about other people's behaviour matter just as much to the determination of efficiency as preferences about one's own. That is why, as we shall explain in the next section, efficiency often positively requires the process-based restrictions the pro-trader objects to. We are not saying that moral interests can be adequately reduced to preferences. We are saying that for the single-minded efficiency-seeker, who presupposes such a reduction, to argue against process-based restrictions on the ground that certain moral interests are 'illegitimate' is doubly confused.

\section{The Comparative Likelihood that Process-based Restrictions and Product-based Restrictions Are Protectionist, Segment Markets, or Are Distributively Unjust}

\section{Protectionism}

We have already encountered the suggestion that process-based restrictions are particularly likely to involve disguised protectionism, in the course of discussing

42 See P. Sands, Principles of Intemational Environmental Law: Frameworks, Standards and Implementation, Vol. 1 (1995) 186-193. 
possible purposes for such restrictions. As we said, the country which disapproves of turtle-unfriendly shrimp fishing and forbids it to its own fishermen may impose the same process-based import restriction on foreign fishermen partly in order to avoid the competitive disadvantage to local fishermen that would result from application of the prohibition to them alone. This looks to many people like protectionism. But that is a misconception.

The first point to make in response is that the purpose of avoiding competitive disadvantage is often not the dominant purpose. Often the primary motivation for the import restriction, like that of the internal prohibition, is simply concern for turtles. Usually, the domestic fishermen would have preferred to operate without any restriction on their choice of technology. So the domestic ban on turtle-hostile technology will have been passed in response to environmental concerns, over the fishermen's objection. It is true that once the domestic ban is in place, the interests of the environmentalists and the domestic fishermen converge on the import restriction. But if the environmentalists could get the domestic ban enacted over the objection of the domestic fishermen, theirs is presumably still the strongest voice when the import restriction is in issue.

Of course, the domestic ban may not have been passed separately. We can imagine that if the domestic ban and the import restriction were imposed as a package, the domestic fishermen may have supported the whole package because the cost to them of the domestic ban was less than the anticipated benefit from the import restriction. In such a case, it could even be that the domestic fishermen were the strongest voice in support of the package, and it would then be reasonable to view the import restriction as protectionist. But there is no reason at all to assume this is the standard case. While it is appropriate and necessary for dispute settlement agencies to inquire on a case-by-case basis into whether a restriction which confers significant competitive protection on local producers is disguised protectionism (where this inquiry is specifically mandated by the treaty), ${ }^{43}$ there is no ground for a categorical presumption against process-based restrictions.

The second point is that if the legislature's dominant concern is with turtles, then the import restriction is not protectionist in any sense. Even the secondary purpose of eliminating the competitive disadvantage to local fishermen, far from being protectionist, is required by considerations of efficiency. Why is that? In a nutshell, because foreign fishermen create the same externality by killing turtles that domestic fishermen do. That is, after all, the reason for the ban on turtle-unfriendly fishing by domestic fishermen. The voters of the country want to preserve turtles, so turtle-unfriendly fishing creates an externality which the ban on such methods is designed to internalize. But, as we say, the use of turtle-unfriendly methods by foreign fishermen creates the very same externality, and efficiency requires that that externality also be internalized, both (a) to avoid the inefficient killing of turtles and (b) because if foreign fishermen are allowed to impose an externality which domestic

43 For example, the chapeau or preambular paragraph of Article XX. 
fishermen are required to internalize, this will distort the allocation of production between foreign and domestic fishermen.

Many people seem to believe that if the domestic ban is first imposed by itself, that creates a comparative advantage in foreign fishermen, which the import restriction then improperly takes away. This is a mistake. The domestic ban by itself creates a competitive advantage for foreign fishermen, but if the foreign fishermen in fact impose the same externality, this competitive advantage does not reflect a comparative advantage of the sort that is relevant to the achievement of efficiency. Comparative advantage in that efficiency-relevant sense depends on the facts about production functions and preferences, but not on the legal facts. (The reader who is in doubt might reflect on the fact that a standard protectionist tariff does not create a comparative advantage for local producers. It gives them a competitive advantage which is objectionable precisely because the legal advantage is not based in any real comparative advantage.) Where the locals and the foreigners create the same externality, comparative advantage is distorted by restricting the one but not the other. ${ }^{44}$

It may seem that we have cheated by consulting only the preferences about turtles of the importing country. By hypothesis, the home country of the foreign fishermen does not regulate to protect turtles, so we may assume they care less about them. It might then seem that the foreign fishermen create no externality by their fishing. But this also is a mistake. If the citizens of the importing country care equally about the turtles killed by locals and the turtles killed by foreigners, then both local and foreign fishermen create the same externality. If citizens of the foreign country also cared, that would create a further externality; and if they do not care, neither local nor foreign fishermen can be charged with an externality grounded in the foreign country's preferences, But that does not change the fact that all fishermen, foreign as well as local, are imposing an externality on the importing country's citizens who value turtles.

We have heard the objection at this point, that if the importing country and the producing country disagree about the importance of turtles, then the question is "Who gets to say whether there is an externality?' But if the importing country prefers that turtles not be killed, then the killing of turtles (by anyone) simply does impose an externality. There is no further question about 'who gets to say'. Ironically, if the

44 There is another context in which economists speak of 'comparative advantage', and in which the existing legal regime is relcvant. We may look at price ratios between specifed products in autarkic countries to predict trade flows after explicit trade barriers are removed, and we may summarize the facts about comparative price ratios under the prevailing legal regimes by speaking of 'comparative advantage'. But predicting trade flows under conditions which take existing regulatory regimes for granted is not the same as identifying the conditions under which trade will promote efficiency, so this is not the sense of 'comparative advantage' which is relevant to the standard claims about comparative advantage and efficiency. Removing traditional trade barriers will promote efficiency in a world where there are no other impediments to efficiency, such as unintenalized externalities, but removing barriers between economies, one of which requires its producers to internalize some externality and the other of which does not, is likely to be ineficient, for' standard 'second-best' reasons. We are grateful to Henrik Horn for encouraging us to make this distinction explicit. 
importing country claims to rely, not on a bare preference, but on a moral truth that endangered species should not be driven to extinction, then it is more plausible to claim there is an issue about 'who gets to decide' this disputed moral question, since even the importing country would concede that their restriction is unjustified if their moral view is mistaken. At this point, however, the only plausible answer to the question 'who gets to decide' is that the producing country gets to rely on its moral belief in regulating how its fishermen may fish, and the importing country gets to rely on its moral belief in regulating which goods may enter the country.

The 'who gets to say' objection may actually be meant to raise a somewhat different issue, which is this: granting that there is an externality, who should pay for the internalization? Perhaps if the United States wants to exclude shrimp taken without turtle-excluder devices, it should have to buy such devices for Indian shrimp fishermen. (It is worth emphasizing that this issue about who should pay the cost of internalization casts no doubt on the desirability, for efficiency reasons, of the import restriction itself. If the importing country must pay, it is in effect buying the right to impose the restriction.) No doubt in many cases assistance from the rich importer to the poor producers would be the decent thing. But it would not be sensible to have a general rule that the country with environmental (or other similar) concerns must always pay the country that threatens those concerns to clean up its act. For one thing, as Howard Chang has shown, such a rule could create perverse incentives for the producing country and lead to losses in efficiency. ${ }^{45}$ For another, this sort of dispute does not always pit a big, rich importer against a small, poor producer. (Once again, remember the dispute between the United States and the European Union about genetically modified foods.) Finally, notice that we do not in general think that when consumers (or consumer nations) change their tastes, they have an obligation. to pay the costs for producers to retool to satisfy the altered demand. Producers bear those costs, which they will then largely recoup in the prices of the newly desired goods. In principle, there is no reason why the same should not happen when the change of taste concerns preferences about processing history. In some cases, unfortunately, the transition costs may be prohibitive for poor producers in small countries. That is a genuine problem. But it is not unique to process-based restrictions (it can also arise with product-based restrictions), and it is not sensibly addressed by a general ban on process-based restrictions.

It is worth pointing out that even a trading system which allows non-protectionist process-based restrictions without payment (such as we claim the WTO is) is a sort of compromise and does not leave the rich country to the untrammelled exercise of its economic power. Even with the import restriction, internalization will be incomplete. The same externality in the turtle-loving importing country is created by the foreign shrimpers' fishing for that portion of their catch which is sold in other markets. But that part of the externality the importing country can do nothing about, because it cannot impose country-based restrictions (unless they are justified under Article XX) or direct regulation of the behaviour of foreign shrimpers (which would truly be

45 'Carrots, Sticks and International Externalities', 17 International Review of Law and Economics (1997) 309. 
extra-territorial), As a result, there is also a compromise on the question of who bears the cost of internalization. Where production for sale in the importing country's market is concerned, the cost will be borne in the first instance by the producer (though as we have seen, much of the cost will be passed along in the purchase price). Where production for sale in other less turtle-friendly markets is concerned, the externality will be internalized only if the turtle-friendly country bribes the producers. (In the end, the producer gets compensated either way, except for transition barriers.)

It is not essential to our analysis of the turtle case that the local and foreign fishermen are threatening the same turtles, or even that they might be. If the importing country has a local ban on the use of leg-traps to trap animals for fur, on the ground that such trapping is cruel and immoral, and if it is as offended by the cruel trapping of animals in foreign countries as at home, then foreigners' leg-trapping of their local animals creates the same externality in the importing country as does locals' leg-trapping at home. Once again, efficiency in fact requires the extension of the local ben by an import restriction. In contrast, if a local mining industry is saddled with costly rules about repairing landscape damage from strip-mining, and if the ground of these rules is merely aesthetic preference regarding the local landscape, then efficiency does not require a comparable import restriction. Unrepaired strip-mining abroad creates no externality in the importing country. If the citizens of the foreign country do not care about the same feature of their landscape, then the foreign strip-miners will, in this respect, enjoy a genuine comparative advantage. The local mining industry might lobby for an import restriction (with cries of "level playing field'), but in this case such a restriction would be protectionist. ${ }^{46}$

We see that there are two complementary mistakes to be avoided about the relation between the regulatory regimes, competitive advantage, and comparative advantage. On the one hand, it does not follow from the fact that Utopia forbids turtle-unfriendly shrimp fishing and Barataria allows it that Baratarian shrimpers have a true comparative advantage. On the other hand, it does not follow from the fact that Utopia forbids unrepaired strip-mining and Barataria allows it that Utopian strip-miners should be protected against imports of Baratarian coal. In both cases, whether import restrictions conduce to efficiency depends on facts about preferences which cannot be read off of the legal situation.

There is a reason why our discussion so far has focused on import restrictions implementing environmental concerns, and we are now in a position to appreciate that reason. Even though it has become a commonplace to regard 'trade and the environment' and 'trade and labour conditions' as closely analogous problems, laws regarding labour conditions tend to be different in important respects that make them significantly less eligible for incorporation into import restrictions. Many labour laws are primarily redistributive in nature; few labour laws are justified on the ground that

46 See the discussion of a very similar example in Chang, supra note 36, at 2191. For a critique of this kind of 'level playing field'-based restriction, sce Howse and Trebilcock, 'The Free Trade-Fair Trade Debate: Trade, Labor, and the Environment', in J.S. Bhandari and A.O. Sykes, Economic Dimensions in International Law: Comparative and Empirical Perspectives (1997) 186-234, at 225-226. 
they compel the internalization of externalities. Similarly, most labour legislation (minimum wage legislation, for example) does not enforce moral norms whose precise terms even the enacting country would regard as universally binding. (Laws against slave labour or child labour are much more likely to be thought of as based on such universal norms, and they are therefore much better candidates for grounding non-protectionist import restrictions. $)^{47}$ In sum, labour laws are more often analogous to laws about strip-mining, where equalization is not required, than to laws about shrimp fishing, where it is.

One objection to applying the importing country's minimum wage requirement to imports is that the importing country's minimum wage may be totally inappropriate to the economic conditions in the producing country. Something similar can be true in the environmental area. For example, the circumstances in which foreign shrimpers fish may be such that they can reduce their turtle mortality with a less expensive technology than is required of fishermen from the importing country. In the extreme case, the foreign fishermen may trawl in waters where there simply are no turtles. To require them to install turtle-protective technology would be pointless, and an import restriction which banned their shrimp unless they had such technology would unquestionably be protectionist. Notice that in this case, the foreign shrimpers have a genuine comparative advantage (not just law-created), once the importing country decides that it cares about turtles. Requiring them to install useless technology would deprive them of it. The basic point remains even when foreign shrimpers do catch and kill some turtles. All they should be required to do is to reduce their turtle mortality to the same level as the fishermen of the importing country (when these are using the technology prescribed for them). Then the foreign fishermen and the locals will be imposing the same residual, uninternalized externality. If the foreign fishermen can reduce their turtle mortality by a less expensive technology than the local fishermen, they should not be required to use the same, expensive technology. Process-based import restrictions should be stated in terms of the results of technology change, at least where there is any likelihood that foreigners can achieve by a different technology the same results that the required technology achieves for locals.

We have seen that process-based restrictions are not necessarily protectionist. Notice also that everything we have said about process-based restrictions we could have said about product-based restrictions. Product-based import restrictions also have the incidental effect of protecting local producers against competitive injury. Indeed, it is easy enough to imagine cases in which the whole package of local product-based restriction and 'supporting' product-based import restriction might be instigated mainly by domestic producers for protectionist reasons. But this does not

47 See Howse, 'The World 'Trade Organization and the Protection of Workers' Rights', 3 Journal of Small and Energing Business Law (1999) 131; Mocrudden, 'International Economic Law and the Pursuit of Human Rights: $\triangle$ Framework for Discussion of the Legality of "Selective Purchasing Laws" under the WTO Government Procurement Agreement', Journal of International Econonic Law (1998). 
lead anyone to suggest a blanket presumption against product-based restrictions. There is no better reason for a blanket presumption against process-based restrictions.

One final remark, It is often said that the problem of process-based restrictions requires us to strike a balance between free trade and national autonomy. But we have seen that the preferences that are standardly thought of as weighing only on the 'autonomy' side of the balance must in fact be honoured if the primary goal of free trade, which is efficiency, is to be achieved. With regard to those preferences, the values of efficiency and autonomy do not conflict. They point in the same direction. (And GATT values trade as a means to efficiency. It does not promote trade-for-trade'ssake, as is shown by the disfavouring of export subsidies, for example.) There are areas where GATT does resolve a conflict (at least short-term) between the value of trade/efficiency and other values - sometimes giving overriding weight to the other values, such as national security, or protecting the balance of payments, or economic development, But non-protectionist process-based import restrictions require no such balancing. The supposed conflict between free trade and autonomy is illusory.

\section{Market Segmentation}

Another possible criticism of process-based restrictions is that they are likely to lead to market segmentation, which may encourage greater market imperfection or prevent the achievement of economies of scale. The main reason markets might segment is that foreign producers might not want to undertake the cost of revamping their processes to meet the new restrictions. It is also possible that foreign producers might be legally prevented from meeting the terms of the import restriction by laws in their home countries that impose incompatible requirements, ${ }^{48}$ but as we have suggested earlier, this does not seem likely to be a common problem. Here, as elsewhere, we have two overlapping responses: (1) 'market segmentation' is not always a bad thing; and (2) process-based restrictions seem no more likely than product-based restrictions to lead to genuinely undesirable market segmentation (and may even be less likely to do so).

As to the first point, if some country forbids the import of shrimp caught in turtle-hostile nets, and if this is done out of genuine environmental concern and not for protectionist reasons, then this country is announcing, in effect, that it regards shrimp caught with turtle-friendly nets and shrimp caught with turtle-hostile nets as significantly different products. But if turtle-friendly shrimp and turtle-hostile shrimp are different products, there is no objection to market segmentation - to the emergence of one set of producers of turtle-friendly shrimp selling to one set of consumers, and another set of producers of turtle-hostile shrimp selling to a different set of consumers. That is what we should expect. Nor should we be troubled that economies of scale may be lost that could be achieved if consumers of shrimp and voters were all indifferent to the fate of turtles. To be sure, market imperfections are

48 See, OECD, Processes and Production Methods (PPMs): Conceptual Eramework and Considerations on Use of PPM-based Trade Measures (1994) 9. 
more likely when a market is thinner, but that is not a consideration that would normally prompt us to force consumers to buy a product they do not want.

Turning now to the comparison between process-based and product-based restrictions: we see no reason to think process-based restrictions are systematically more likely than product-based restrictions to cause market segmentation of any sort, and there is reason to think they are actually less likely to cause the sort of market segmentation that is genuinely objectionable. As to the first point, process-based restrictions will cause more market segmentation only if either (a) it generally costs more for a producer to reorganize his activity to comply with a process-based restriction than to reorganize to comply with a product-based restriction, or (b) the producer's home country is more likely to have processing requirements incompatible with the importer's process-based restrictions than to have product requirements incompatible with the importer's product-based restrictions. Neither of these propositions strikes us as intuitively compelling. ${ }^{49}$

With regard to the matter of costs, is it more costly to acquire turtle-excluder devices, or to abandon leg-traps, or to discontinue animal-testing of cosmetics (all actual or plausible process-based restrictions), than it is to restructure automobile production lines to add on catalytic converters, or to dispense with aerosol propellants, or to produce freon-free refrigerators (actual or plausible product-based restrictions)? Our list of examples is intentionally biased, but such a list makes the point that there is no reason to think there is any systematic difference, to the disadvantage of process-based restrictions, which would justify a presumption against process-based restrictions.

As to the issue of incompatibility between the producer's home-country regulation and the import restriction, it actually seems substantially less likely that a process-based restriction will involve such incompatibility than that a product-based restriction will. Not many countries require that shrimpers use turtle-unfriendly nets, or leg-traps, or that cosmetics be tested on animals, Of course, not many countries forbid catalytic converters either, or require freon in refrigerators. But at a more mundane level there are many cases of flat-out incompatibility between product-

19. Actually, there is an ambiguity in this talk of 'incompatibility'. There are two ways Country $A$ and Country B might have 'incompatible' requirements. One possibility is that country $A$ has requirements on goods produced for its market which are incompatible with Country B's requirements on goods produced for its market. This means no single item is eligible for sale in both markets, but it leaves open the possibility that producers in either country might produce goods for both markets. The second possibility is that Country A might forbid its producers to meet the requirements Country B imposes on goods for its market. Now, the first type of incompatibility, which is the one we are mainly concerned with in the text that follows, seems more likely to occur in connection with product-based requirements, for reasons we point out in the text. And it may not infrequently be a source of genuinely inefficient segmentation. The second type of incompatibility, which would legally prevent a producer in Country $A$ from operating two production lines for the two countries' markets, may indeed be more likely in connection with process-based restrictions, But it is still not likely to be common, and when it occurs, the segmentation it causes will not be ineficient (assuming each country's rules genuinely reflect its own non-protectionist preferences), 
specifications in different countries, especially in connection with labelling and packaging. ${ }^{50}$

Not only is there more likely to be genuine incompatibility in regard to product-based restrictions, but the market segmentation caused by this incompatibility is more likely to be inefficient, because the differences in requirements, especially about packaging and labelling, are less likely to correspond to real differences in underlying preferences. Often the precise rules about packaging and labelling matter less than having some rules, for the sake of consistency. So different countries may end up with different rules, just because each needs some rules or other. Of course, once a particular set of rules is in force for domestic production, then admitting nonconforming foreign products would undermine the desired consistency. But even if the desire for consistency is genuine and strong, this is the sort of case that cries out for international harmonization. Harmonization would avoid inefficient segmentation.

Note finally that product-based restrictions will often have to be enforced by inspection or analysis of a product at the border, an expensive undertaking that increases the transaction costs to trade. Given the challenges of conformity assessment in areas like food safety, it may well be more efficient to formulate regulations in terms of the quality of the process rather than characteristics the product must possess. Indeed, a noticeable trend in risk regulation in a number of different areas is to focus on quality control in the production process, not the specifications of the finished product. ${ }^{51}$

\section{Distributive Justice}

We have already encountered the issue of distributive justice in two contexts - in connection with the claim that process-based restrictions imposed by powerful countries are 'coercive', and in connection with the issue of 'who should pay the costs of internalization?' In both of these contexts our conclusion was that although there are real problems, they are not sensibly addressed by a ban on process-based restrictions. Such a ban is both too narrow (because the same problems are associated with product-based restrictions) and too broad (because many disputes over process-based restrictions involve countries that are economic equals).

Beyond this, there is not much that can usefully be said about the large issues of international distributive justice in a paper on process-based restrictions. The objection to such restrictions is that having to meet them increases the costs of production in poor countries, thus making their products less competitive, which leads to lower rates of export-led growth, more unemployment and lower incomes for workers and their families (who are already worse off than their counterparts in richer

50 It might seem that there is a danger from process-based restrictions that, for example, importing country $X$ will require round turtle-excluder devices and importing country $Y$ will require square turtle-excluder devices, even though both sorts of device are equally effective. This would indeed lead to inefficient segmentation, but it cannot happen, because, as we have explained elsewhere, in principle all an importing country is entitled to require through its process-based restrictions is equivalent results in avolding the undesired effects. We are grateful to a participant in our WTO economic and legal seminar for raising this example,

5. See $\Lambda$ dams, 'ISO 9000 and HACCP Systems', 49 Food and Drug Law Joumal (1994) 603. 
countries). But the overall impact of such requirements is controversial, and may vary from case to case. For example, the OECD has argued that in almost all cases compliance with core labour standards is consistent with export-driven growth strategies, and indeed complementary to them. ${ }^{52}$ Similarly, in some contexts the need to meet higher environmental standards may have positive dynamic effects on innovation, technology transfer and growth. ${ }^{53}$ There are to be sure some contexts where process-based restrictions, or indeed other measures taken by individual countries on an uncoordinated basis, may not solve a particular problem in a distributively just fashion, and in such cases a negotiated agreement that divides the responsibility for the common problem between the different countries may be desirable (for example the Montreal Protocol). Where such explicit agreements have been achieved, there may indeed be reason to discipline the use of process-based restrictions by interpreting GATT obligations in light of these subsequent treaty obligations. But there is no basis for a presumption that process-based restrictions in general conflict with reasonable principles of transnational distributive justice.

\section{Conclusion}

The final worry is that allowing process-based measures would threaten the integrity of the trading system. ${ }^{54}$ Undoubtedly, the interaction of process-based measures with liberal trading norms raises important policy and conceptual challenges. But as we have seen, these challenges are in no way distinctive to process-based measures; they arise in connection with product-based measures as well. Even if process-based measures did raise challenges unique to them, it would still be a questionable strategy to simply avoid the challenges by prohibiting such measures across-the-board. As the Appellate Body emphasized in the Turtles case, the international law of treaty interpretation requires the interpreter to apply the actual text of the treaty to the specific measures at issue in the dispute; she must not (as the panel below had done in Turtles) avoid such case-by-case analysis by holding entire classes of measures to be illegal on the basis of a broad notion of what is required for the integrity of the WTO system.

There are, of course, legitimate rationales in some cases for simple, bright-line rules. However, as the Appellate Body has emphasized, the application of the concept of non-discrimination in Article III is inherently a highly contextual exercise. ${ }^{55}$ This is

52 OECD, Trade, Employment and Labor Standards: A Study of Core Workers' Rights and International Trade (1996) 40 .

53 See Stewart, 'Environmental Regulation and International Competitiveness', 102 Yale Law Journal (1993) 2039.

54 John Jackson has observed: 'Trade policy experts are concerned that if a nation is allowed to use the process characteristic as the basis for trade restrictive measures, then the result would be to open a Pandora's box of problems that could open large loopholes in the GATT.' 'World Trade Rules and Environmental Policies: Congruence or Conflict?', 49 Washington and Lee Law Review (1992) 1227 at 1243.

55 Japanesc Alcohol, supra note 27 , at 19--22. 
true for a wide range of regulations that are not process-based. One could argue for the replacement of the broad anti-discrimination norm in Article III with a series of specific, bright-line rules designed to avoid the need for context-sensitive judgment. (The SPS and TBT Agreements could be regarded as steps in this direction, in limited contexts; but even under those agreements, the lines are not so bright as all that. $)^{56}$ However, we know of no legal system, domestic or international, that has a non-discrimination norm as an essential component, that has been able to replace an articulation of that norm requiring contextual judgment with a set of rules susceptible of relatively mechanical application. The product/process distinction has particularly little to recommend it as a bright-line rule for the world trading system. It would risk infecting the jurisprudence of GATT with arbitrariness and incoherence at a point where there are highly visible effects on domestic policies, and the legitimacy of the trading system itself is therefore very much at stake.

56. Agreement on Technical Barriers to Trade; Agrecment on Sanitary and Phytosanitary Measures; the main operative provisions of these agreements impose procedural requirements on the claboration of regulations, which may tend to make that process more rigorous and transparent, but in terms of substantive justification, rely on general jurisprudential notions such as ideas of rational basis and connoction, or least restrictive mcans to achieving a given objective. 